\title{
DAMPAK TPA PUTRI CEMPO TERHADAP PERMUKIMAN
}

\author{
Nurhaliza Dewi Ramadhanti' ${ }^{1}$, Winny Astuti ${ }^{1}$, Rufia Andisetyana Putri ${ }^{1}$ \\ ${ }_{1}$ Program Studi Perencanaan Wilayah dan Kota, Fakultas Teknik, Universitas Sebelas Maret
}

\begin{abstract}
Abstrak
Tempat Pemrosesan Akhir (TPA) Putri Cempo merupakan tempat berlangsungnya pemrosesan akhir sampah yang berasal dari seluruh wilayah Kota Surakarta. Pada area TPA Putri Cempo dilakukan berbagai kegiatan, mulai dari pemilahan sampah, pengumpulan dan pengangkutan, daur ulang, penimbunan dan pengolahan air lindi. TPA Putri Cempo terletak berbatasan langsung dengan kawasan permukiman di Kelurahan Mojosongo dan Desa Plesungan. Penelitian ini bertujuan untuk mengetahui dampak aktivitas pengelolaan sampah TPA Putri Cempo terhadap kualitas permukiman di sekitarnya. Penelitian ini menggunakan metode kuantitatif dengan teknik analisis deskriptif. Teknik analisis deskriptif digunakan untuk menganalisis dampak aktivitas pengelolaan sampah dilihat dari tujuh aspek kualitas permukiman, yaitu (1) kondisi fisik dan tata bangunan, (2) kondisi sarana dan fasilitas umum, (3) kondisi prasarana dasar, (4) kenyamanan dan keamanan lingkungan, (5) lokasi dan aksesbilitas permukiman, (6) kondisi lingkungan alami, dan (7) perekonomian. Dari hasil analisis diperoleh bahwa aktivitas pengelolaan sampah TPA Putri Cempo mengakibatkan dampak terhadap berbagai aspek kualitas permukiman di sekitarnya. Pada zona radius $\leq 500 \mathrm{~m}$, aktivitas pemilahan sampah berdampak pada aspek fisik dan tata bangunan, kondisi sarana, lokasi dan aksesibilitas, serta perekonomian. Aktivitas pengumpulan dan pengangkutan sampah berdampak pada aspek keamanan dan kenyamanan, serta lokasi dan aksesibilitas. Aktivitas daur ulang sampah berdampak pada aspek perekonomian. Aktivitas penimbunan akhir berdampak pada aspek kondisi lingkungan alami, kondisi prasarana, keamanan dan kenyamanan, lokasi dan aksesibilitas, serta perekonomian. Terakhir, aktivitas pengolahan air lindi berdampak pada aspek kondisi lingkungan alami. Sementara itu, pada radius >500-1000 m, aktivitas pemilahan sampah tidak mengakibatkan dampak terhadap kualitas permukiman. Aktivitas pengumpulan dan pengangkutan sampah berdampak pada aspek keamanan dan kenyamanan. Aktivitas daur ulang berdampak pada aspek perekonomian. Aktivitas penimbunan akhir berdampak pada nilai lokasi dan aksesibilitas. Terakhir, aktivitas pengolahan air lindi tidak mengakibatkan dampak terhadap kualitas permukiman.
\end{abstract}

Kata kunci: kualitas permukiman; pengelolaan sampah; TPA Putri Cempo

\begin{abstract}
TPA Putri Cempo is the landfill site where the final process of solid waste disposal takes place from all of Kota Surakarta area. In the TPA Putri Cempo, several solid waste management activities are conducted as follows, waste sorting, waste collection and transportation, waste recycling, landfilling, and leachate treatment. TPA Putri Cempo is adjacent to the settlement area of Kelurahan Mojosongo and Desa Plesungan. The research aims to analise the impacts of solid waste management activities in TPA Putri Cempo on the quality of its surrounding settlement. This research uses a quantitative method with a descriptive analysis technique. Seven aspects of settlement quality were included in the assessment, (1) buildings condition and spatial organization, (2) condition of public facilities, (3) condition of infrastructures, (4) safety and amenity of the neighborhood, (5) settlement location and accessibility, (6) condition of the natural environment, and (7) economic condition. The result reveals that solid waste management activities of TPA Putri Cempo have impacts on the quality of its surrounding settlement. In the settlement area within $\leq 500 \mathrm{~m}$ radius, waste sorting activity has impact on the buildings condition and spatial organization, condition of public facilities, settlement location and accessibility, as well as economic condition. The waste collection and transportation activity affect the safety and amenity of the neighborhood, as well as the settlement location and accessibility. The waste recycling activity only affects the economic condition. The landfilling activity affects the condition of infrastructures, safety and amenity of the neighborhood, settlement location and accessibility, and economic condition. The leachate treatment activity affect the condition of the natural environment. While in the settlement area within $>500-1000 \mathrm{~m}$ radius, the waste sorting activity does not affect the settlement quality. The waste collection and transportation activity affect the safety and amenity of the neighborhood. The waste recycling activity affect the economic condition. The landfilling activity affect the settlement location and accessibility. Lastly, the leachate treatment activity does not affect the settlement quality.
\end{abstract}

Keywords: settlement quality; solid waste management; TPA Putri Cempo 


\section{PENDAHULUAN}

Sampah adalah bahan berbentuk padat maupun semi padat yang berasal dari aktifitas manusia dan hewan dan dibuang karena dianggap tidak memiliki manfaat bagi pemiliknya (Tchobanoglous, 1993 dalam Lesmana, 2016). Sebagian besar wilayah di Indonesia masih menggunakan paradigma konvensional dalam pengelolaan sampah, yaitu pemusnahan dengan landfilling pada sebuah TPA (Tempat Pemrosesan Akhir) sampah. Namun, pengelolaan sampah dengan metode open dumping di TPA berpotensi menimbulkan permasalahan baru bagi lingkungan sekitarnya. Beberapa dampak lingkungan yang ditimbulkan di antaranya adalah pencemaran air tanah oleh air lindi yang dihasilkan dalam proses pengolahan sampah, bau sampah yang menyengat, risiko kebakaran akibat gas metana yang dihasilkan sampah, serta risiko penyakit yang ditimbulkan dari bakteri yang terkandung pada sampah (Alam \& Ahmade, 2013).

Dikarenakan banyaknya risiko yang ditimbulkan oleh kegiatan di TPA terhadap kawasan sekitarnya, penentuan lokasi TPA dilakukan dengan mempertimbangkan berbagai persyaratan untuk meminimalisir dampak yang ditimbulkannya. Menurut Peraturan Menteri PUPR No. 19 Tahun 2012 Tentang Pedoman Penataan Ruang Kawasan Sekitar Tempat Pemrosesan Akhir Sampah, kawasan di sekitar TPA harus dilengkapi zona penyangga yang berjarak $500 \mathrm{~m}$ dari batas terluar tapak TPA dengan pemanfaatan sebagai sabuk hijau dan pertanian non pangan atau hutan, serta zona budidaya terbatas berjarak $500 \mathrm{~m}$ dari zona penyangga dengan pemanfaatan untuk kegiatan budidaya terbatas, terutama kegiatan yang berkaitan dengan TPA.

Kriteria jarak TPA terhadap permukiman sangat penting, karena selain sebagai tempat tinggal, juga berfungsi dalam memberi kenyamanan dan perlindungan bagi penghuninya. Kualitas permukiman memiliki peran yang sangat penting dalam mendukung kegiatan manusia yang menunjang perikehidupan dan penghidupannya. Kualitas permukiman dapat dilihat dari beberapa aspek penting di dalamnya seperti yang diungkapkan Dursun dan Saglamer (2009) yaitu (1) Contextual Aspect (aspek kontekstual) yang meliputi karakteristik alami, kenyamanan lingkungan, keamanan, lokasi permukiman, dan aksesibilitas; (2) Spatial Aspect (aspek spasial) yang meliputi karakteristik arsitektural, ukuran bangunan, dan organisasi spasial; (3) Social Aspect (aspek sosial) yang meliputi profil masyarakat, interaksi sosial masyarakat, integrasi sosial penduduk dengan lingkungan, serta organisasi sosial dan administratif; serta, (4) Economic Aspect (aspek perekonomian).

Meskipun telah ditetapkan bahwa penentuan lokasi TPA harus memiliki jarak tertentu dari lingkungan permukiman, kenyataannya, lahan di perkotaan semakin terbatas akibat pertambahan jumlah penduduk, sehingga banyak kawasan permukiman yang berada di tempat yang bukan semestinya, seperti di sekitar TPA sampah. Salah satunya berada di sekitar lokasi TPA Putri Cempo, Kelurahan Mojosongo, Surakarta. TPA yang melayani persampahan di Kota Surakarta dan sekitarnya ini mulai beroperasi sejak tahun 1986 dan memiliki luas area $17 \mathrm{Ha}$. Lokasi TPA Putri Cempo terletak berbatasan langsung dengan kawasan permukiman di Kelurahan Mojosongo (Surakarta) dan Desa Plesungan (Kabupaten Karanganyar). Dalam operasionalnya, TPA Putri Cempo menggunakan metode open dumping, yakni dengan menimbun sampah secara langsung tanpa perlakuan tertentu. Di area tapak TPA dan sekitarnya, juga dilakukan berbagai kegiatan selain penimbunan sampah seperti pengangkutan, pemilahan, daur ulang, dan pengolahan air lindi. Keberadaan TPA Putri Cempo memberi dampak terhadap kualitas permukiman sekitarnya, baik dari aspek kontekstual (karakteristik alami), aspek spasial, aspek sosial, dan aspek ekonomi. Kemudian muncul pertanyaan penelitian, bagaimana dampak aktivitas pengelolaan sampah TPA Putri Cempo terhadap kualitas permukiman di sekitarnya.

\section{KAJIAN PUSTAKA}

\subsection{DEFINISI SAMPAH}

Menurut Tchobanoglous dkk. dalam Lesmana (2016) sampah merupakan bahan buangan berbentuk padat atau semi padat yang berasal dari aktivitas manusia dan hewan yang dibuang karena tidak memiliki manfaat bagi pemiliknya. Sampah dapat diklasifikasikan menjadi beberapa kategori, seperti yang diungkapkan dalam Damanhuri dan Padmi (2010), bahwa di Indonesia, sampah perkotaan yang dikelola oleh Pemerintah Kota di Indonesia sering dikategorikan dalam beberapa kelompok, yaitu sampah dari rumah tinggal atau sampah domestik; sampah dari daerah komersial; sampah dari perkantoran/ institusi; sampah dari jalan, taman dan tempat umum; serta sampah dari industri dan rumah sakit yang sejenis sampah kota. Sedangkan berdasarkan sifatnya, sampah dapat dibedakan menjadi atas sampah organik (meliputi sampah dapur, sayuran 
dan buah-buahan, bunga, dan daun); sampah beracun (meliputi limbah obat-obatan, cat, bahan kimia, kaleng semprot, pupuk, baterai, pestisida, dIl.); recycleable/ dapat didaur ulang (meliputi kertas, kaca, besi, dan plastik).

\subsection{AKTIVITAS PENGELOLAAN SAMPAH PADA TEMPAT PEMROSESAN AKHIR (TPA) SAMPAH}

Dalam Lampiran Peraturan Menteri PUPR No. 3 Tahun 2013 Tentang Penyelenggaraan Prasarana Dan Sarana Persampahan Dalam Penanganan Sampah Rumah Tangga Dan Sampah Sejenis Sampah Rumah Tangga, di lokasi pemrosesan akhir wajib terdapat 4 (empat) aktivitas utama pengelolaan sampah, yaitu pemilahan sampah, daur ulang sampah anorganik, pengomposan sampah organik, dan pengurugan sampah residu di atas lokasi pengurugan. Menurut Pratama (2016), aktivitas pengelolaan sampah yang terjadi di lokasi TPA, antara lain pemilahan sampah, daur ulang sampah, pengomposan (komposting), penjualan hasil pengolahan sampah, penimbunan sampah dan pengolahan air lindi (leachate). Menurut UU No.18 Tahun 2008 Tentang Pengelolaan Sampah, penanganan sampah di TPA terdiri dari pemilahan, pengumpulan, pengangkutan, pengolahan, dan penimbunan sampah residu. Terakhir, menurut Omran dan Gavrilescu (2008), pengelolaan sampah meliputi pengumpulan dan pengangkutan (collection and transportation), pengolahan (treatment), dan pembuangan (disposal).

Tabel 1. Sintesis Pustaka Aktivitas Pengelolaan Sampah di TPA

\begin{tabular}{|c|c|c|c|c|}
\hline $\begin{array}{c}\text { Permen PU No } 3 \text { Th } \\
2013\end{array}$ & Pratama (2016) & $\begin{array}{l}\text { UU No. } 18 \text { Tahun } \\
2018\end{array}$ & $\begin{array}{c}\text { Omran dan } \\
\text { Gavrilescu } \\
\text { (2008) }\end{array}$ & Hasil Sintesis \\
\hline Pemilahan sampah & Pemilahan sampah & $\begin{array}{c}\text { Pemilahan } \\
\text { sampah }\end{array}$ & & Pemilahan sampah \\
\hline - & - & $\begin{array}{l}\text { Pengumpulan } \\
\text { Pengangkutan }\end{array}$ & $\begin{array}{l}\text { Pengumpulan } \\
\text { dan } \\
\text { pengangkutan }\end{array}$ & $\begin{array}{c}\text { Pengumpulan dan } \\
\text { pengangkutan sampah }\end{array}$ \\
\hline Daur ulang sampah & $\begin{array}{l}\text { Daur ulang sampah dan } \\
\text { penjualan hasil daur ulang }\end{array}$ & Pengolahan & Pengolahan & Daur ulang sampah \\
\hline Pengomposan Sampah & $\begin{array}{l}\text { Komposting sampah dan } \\
\text { penjualan komposting }\end{array}$ & & & Pengomposan Sampah \\
\hline $\begin{array}{l}\text { Pengurugan/penimbunan } \\
\text { residu sampah }\end{array}$ & $\begin{array}{l}\text { Penimbunan sampah } \\
\text { (landfilling) }\end{array}$ & $\begin{array}{l}\text { Pemrosesan akhir } \\
\text { sampah }\end{array}$ & Pembuangan & $\begin{array}{l}\text { Penimbunan sampah } \\
\text { (landfilling) }\end{array}$ \\
\hline - & Pengolahan air lindi & - & - & Pengolahan air lindi \\
\hline
\end{tabular}

Berdasarkan Tabel 1, dapat disintesis bahwa aktivitas pengelolaan sampah di TPA terdiri atas 6 tahapan kegiatan yaitu pemilahan sampah, pengumpulan dan pengangkutan sampah, daur ulang sampah, pengomposan sampah, penimbunan sampah, dan pengolahan air lindi. Namun, menurut Umutesi (2018) dan dibuktikan dengan hasil observasi awal yang dilakukan, diketahui bahwa kegiatan pengomposan sampah di TPA Putri Cempo sudah tidak beroperasi sejak tahun 2016, dikarenakan partisipasi masyarakat setempat yang kurang mendukung program tersebut. Oleh sebab itu, dalam penelitian ini, aktivitas pengomposan sampah dieliminasi dari bagian aktivitas pengelolaan sampah di TPA Putri Cempo. Berikut merupakan aktivitas pengelolaan sampah di TPA Putri Cempo.

1. Pemilahan sampah: pengelompokan dan pemisahan sampah sesuai dengan jenis, jumlah, dan/atau sifat sampah

2. Pengumpulan dan pengangkutan sampah: pengambilan dan pengangkutan sampah, dari sumber sampah ke TPS (Tempat Pembuangan Sementara), serta dari TPS ke TPA

3. Daur ulang sampah: pemrosesan sampah untuk dijadikan barang sekunder

4. Penimbunan sampah: penimbunan sampah residu dari proses di atas di lokasi pengurugan atau penimbunan (landfill)

5. Pengolahan air lindi: pengolahan limbah cair yang timbul akibat masuknya air eksternal ke dalam timbunan sampah sebelum dibuang ke lingkungan 


\subsection{KOMPONEN KUALITAS PERMUKIMAN}

Menurut Doxiadis (1970), kualitas permukiman dapat dijustifikasi dalam berbagai cara dalam konteks hubungan tiap individu (man) dengan lingkungan (nature, society, shells, and network) dan keuntungan yang didapat dari hubungannya tersebut. Hubungan individual dengan lingkungan tersebut dapat dilihat dari udara dan kualitasnya, ketersediaan dan kualitas air bersih, sumber daya lahan, aksesibilitas sarana dan fasilitas umum, serta aspek fisik dan aspek sosial. Menurut Dursun dan Saglamer (2009), penilaian kualitas permukiman didasarkan pada: (1) Aspek kontekstual meliputi karakteristik alami, kenyamanan lingkungan, keamanan, lokasi permukiman, dan aksesibilitas, (2) Aspek spasial meliputi karakteristik arsitektural, ukuran bangunan, dan organisasi spasial, (3) Aspek sosial meliputi profil masyarakat, interaksi sosial masyarakat, integrasi sosial penduduk dengan lingkungan, organisasi sosial dan administratif, (4) Aspek ekonomi meliputi kemampuan masyarakat memiliki hunian, kepemilikan hunian permanen, dan preferensi hunian.

Menurut Wesnawa dalam Adi (2013), terdapat 5 komponen utama dalam permukiman, yaitu bangunan rumah (house building), fasilitas rumah (housing facilities), sanitasi (sanitation), kondisi lingkungan (environment condition) dan keindahan serta aspek arsitektural (aestetic and architectural aspects). Selanjutnya, menurut Sunarhadi dan Priyono (2005), komponen indikator kualitas permukiman terdiri atas lima hal utama yaitu aspek lokasi, kependudukan, kondisi bangunan, kondisi prasarana dan sarana dasar, serta kondisi sosial ekonomi. Dilanjutkan menurut Kamp, et al dalam Dursun dan Saglamer (2009), bagian-bagian seperti kondisi alam, ruang terbuka, infrastruktur, lingkungan terbangun, amenitas lingkungan fisik, dan sumber daya alam masing-masing mempunyai pengaruh terhadap kualitas lingkungan permukiman. Berdasarkan hasil sintesis teori-teori di atas, diperoleh komponen kualitas permukiman seperti pada Gambar 1.

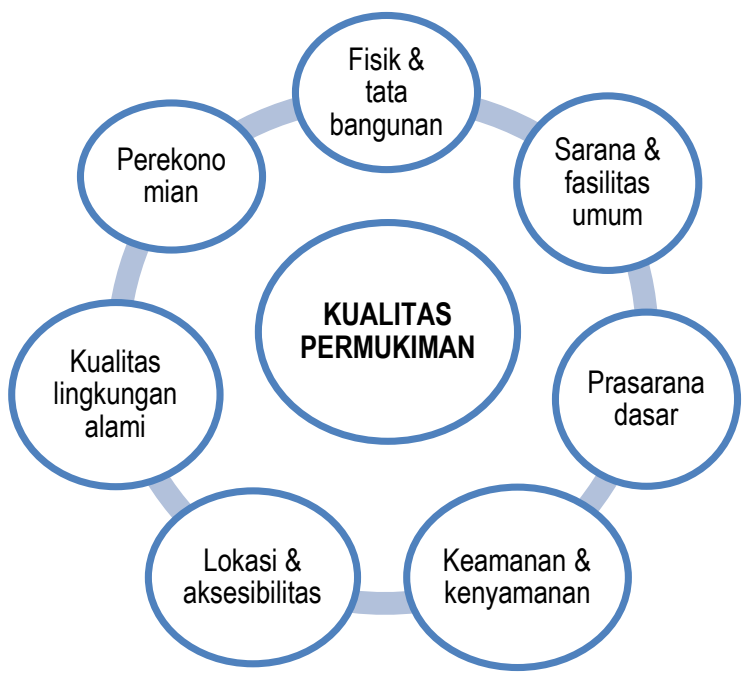

Gambar 1. Komponen Kualitas Permukiman

\subsection{DAMPAK AKTIVITAS PENGELOLAAN SAMPAH TERHADAP KUALITAS PERMUKIMAN}

Beberapa ahli dan peneliti telah mengadakan penelitian mengenai dampak aktivitas TPA terhadap berbagai aspek kualitas permukiman di sekitarnya. Disampaikan dalam Damanhuri dan Padmi (2010) bahwa aktivitas pemilahan sampah di lokasi TPA mengundang para pemulung untuk menghuni wilayah sekeliling TPA dan menciptakan permukiman kumuh berupa barakbarak pemulung dengan tata bangunan yang tidak teratur. Pada kegiatan pemilahan sampah juga dapat memunculkan tempat penimbunan liar yang mengganggu kondisi lingkungan (Karina, Utomo, \& Budijanto, 2013). Pada tahap pengangkutan sampah menuju TPA, sering kali kendaraan pengangkut yang tidak memenuhi standar (muatan terlalu penuh dan kontainer tidak tertutup), menimbulkan sampah berceceran yang merusak nilai visual kawasan (Damanhuri \& Padmi, 2010). Banyaknya kendaraan pengangkut sampah yang berlalu lalang juga menimbulkan dampak berupa gangguan kebisingan serta merusak kondisi jalan yang dilewatinya (Environment Agency UK, 2001). Pada aktivitas pemrosesan dengan metode daur ulang, dapat membuka peluang ekonomi bagi pemulung dan masyarakat sekitar berupa kampung kerajinan daur ulang, dan industri skala 
kecil lainnya (Luong, Giang, Thanh, \& Hung, 2013). Namun, industri daur ulang yang dalam proses pengolahannya tidak menggunakan teknologi yang memadai, akan menimbulkan kerawanan kebakaran serta dampak polusi udara (Giusti, 2009). Pembuangan akhir/penimbunan sampah dapat menimbulkan dampak berupa bau, debu, kebisingan, dan berbagai binatang yang menjadi vektor penyakit seperti lalat, nyamuk, dan tikus. Adanya hal-hal tersebut berdampak pada kesehatan masyarakat, terutama kesehatan kulit, pencernaan dan pernafasan (Damanhuri \& Padmi, 2010; Omran \& Gavrilescu, 2008). Timbunan sampah juga mengurangi nilai visual kawasan (Giusti, 2009). Terjadinya penurunan kondisi lingkungan akibat timbunan sampah di lokasi TPA ini berpotensi menurunkan nilai tanah dan properti yang dibangun di sekitar lokasi TPA (Bandara \& Hettiaratchi, 2010). Kondisi TPA yang overload juga akan berdampak buruk terhadap lingkungan yaitu tersumbatnya aliran sungai dan drainase yang akan menyebabkan banjir ataupun genangan (Nugroho, 2017). Sedangkan pada aktivitas pengolahan air lindi, air lindi yang merupakan air hasil dekomposisi sampah, dapat meresap dan mencemari air tanah yang berakibat pada kerusakan vegetasi, dan timbulnya gas rumah kaca karena emisi biogas yang tidak dikelola (Omran \& Gavrilescu, 2008).

Berdasarkan tinjauan literatur mengenai dampak aktivitas pengelolaan sampah TPA dan hasil sintesis komponen kualitas permukiman. Tabel 2 merupakan sintesis literatur dampak aktivitas pengelolaan sampah TPA terhadap kualitas permukiman di sekitarnya.

Tabel 2. Hasil Sintesis Dampak Aktivitas Pengelolaan TPA terhadap Kualitas Permukiman

\begin{tabular}{|c|c|c|}
\hline $\begin{array}{c}\text { Aktivitas Pengelolaan } \\
\text { Sampah }\end{array}$ & $\begin{array}{l}\text { Aspek Kualitas } \\
\text { Permukiman Terdampak }\end{array}$ & Dampak Aktivitas Pengelolaan Sampah \\
\hline $\begin{array}{l}\text { Dampak pemilahan } \\
\text { sampah }\end{array}$ & $\begin{array}{l}\text { - Fisik dan tata bangunan } \\
\text { - Perekonomian } \\
\text { - Sarana dan fasilitas } \\
\text { umum } \\
\text { - Lokasi dan aksesibilitas }\end{array}$ & $\begin{array}{l}\text { - } \text { Adanya barak-barak pemulung yang tidak teratur } \\
\text { - Potensi ekonomi dari hasil pemilahan sampah } \\
\text { - Pemanfaatan RTH sebagai tempat penimbunan hasil } \\
\text { - Pemilahan sampah } \\
\text { - Penyempitan jalan akibat timbunan hasil pemilahan sampah }\end{array}$ \\
\hline $\begin{array}{l}\text { Dampak pengumpulan dan } \\
\text { pengangkutan sampah }\end{array}$ & $\begin{array}{l}\text { - Keamanan dan } \\
\text { kenyamanan } \\
\text { - Lokasi dan aksesibilitas }\end{array}$ & $\begin{array}{l}\text { - } \text { Tingginya kebisingan } \\
\text { - Timbulan ceceran sampah } \\
\text { - Kerusakan jalan }\end{array}$ \\
\hline $\begin{array}{l}\text { Dampak daur ulang } \\
\text { sampah }\end{array}$ & $\begin{array}{l}\text { - Kualitas lingkungan alami } \\
\text { - Keamanan dan } \\
\text { kenyamanan } \\
\text { - Perekonomian }\end{array}$ & $\begin{array}{l}\text { - Polusi udara akibat proses daur ulang } \\
\text { - Kerawanan kebakaran } \\
\text { - Potensi ekonomi usaha dan industri daur ulang }\end{array}$ \\
\hline $\begin{array}{l}\text { Dampak penimbunan akhir } \\
\text { sampah }\end{array}$ & $\begin{array}{l}\text { - Kualitas lingkungan alami } \\
\text { - Prasarana dasar } \\
\text { - Lokasi dan aksesibilitas } \\
\text { - Perekonomian } \\
\text { - Keamanan dan } \\
\text { kenyamanan }\end{array}$ & $\begin{array}{l}\text { - Polusi udara dan timbulan debu } \\
\text { - Penyumbatan saluran drainase dan sungai akibat kapasitas } \\
\text { TPA yang telah overload } \\
\text { - } \text { Rendahnya nilai tanah dan properti yang dibangun di sekitar } \\
\text { lokasi TPA } \\
\text { - Potensi peternakan sapi pemakan sampah organik } \\
\text { - } \text { Gangguan kesehatan pernafasan, pencernaan, dan iritasi }\end{array}$ \\
\hline $\begin{array}{l}\text { Dampak pengolahan air } \\
\text { lindi }\end{array}$ & $\begin{array}{l}\text { - Kualitas lingkungan alami } \\
\text { - Perekonomian }\end{array}$ & $\begin{array}{l}\text { - Rendahnya kualitas air tanah dangkal } \\
\text { - } \text { Kerusakan vegetasi } \\
\text { - Peluang ekonomi dengan pengolahan air lindi sebagai pupuk } \\
\text { cair }\end{array}$ \\
\hline
\end{tabular}




\section{METODE PENELITIAN}

Metode penelitian memuat pendekatan penelitian, ruang lingkup wilayah, teknik pengumpulan data, serta teknik analisis yang digunakan untuk mengetahui dampak aktivitas pengelolaan sampah TPA Putri Cempo terhadap kualitas permukiman di sekitarnya.

\subsection{PENDEKATAN PENELITIAN}

Penelitian mengenai dampak aktivitas jaringan pengelolaan sampah terhadap kualitas permukiman ini menggunakan pendekatan kuantitatif. Penelitian kuantitatif berlandaskan pada filsafat positivisme yang memandang realitas/gejala/fenomena dapat diklasifikasikan, relatif tetap, konkrit, teramati, dapat diukur, dan hubungan gejala bersifat sebab-akibat (Sugiyono, 2014). Proses penelitian kuantitatif bersifat deduktif yang berarti bahwa penelitian ini didahului dengan proses menggali teori tentang dampak aktivitas pengelolaan sampah terhadap kualitas permukiman sebagai hipotesis, selanjutnya dilakukan analisis data secara kuantitatif dengan statistik deskriptif menggunakan data-data empiris, sehingga pengambilan kesimpulan penelitian dilakukan berdasarkan hasil uji hipotesis dengan menggunakan data empiris tersebut.

\subsection{RUANG LINGKUP WILAYAH}

Penetapan ruang lingkup wilayah dilakukan berdasarkan teori jangkauan dampak TPA terhadap sekitarnya. Menurut Barzehkar dkk (2019), dampak aktivitas TPA dapat menjangkau radius $1000 \mathrm{~m}$ dari batas terluar TPA. Sedangkan menurut Guiqin dkk. (2009) dan Mornya dkk. (2010), risiko dampak TPA hanya menjangkau radius $500 \mathrm{~m}$ dari batas terluar TPA. Berdasarkan beberapa teori yang dikemukakan di atas, ada yang menyebutkan bahwa jarak radius wilayah yang berpotensi terkena berbagai dampak aktivitas TPA adalah sebesar $500 \mathrm{~m}$ hingga $1000 \mathrm{~m}$ dari batas terluar tapak TPA. Maka dari itu, untuk mengetahui secara lebih mendalam mengenai dampak aktivitas TPA Putri Cempo terhadap kualitas permukiman di sekitarnya, penelitian dilakukan dengan melakukan pengamatan variabel penelitian pada kawasan permukiman beradius 1000 $\mathrm{m}$, yang selanjutnya dibagi atas dua zona, yaitu zona berjarak $\leq 500 \mathrm{~m}$ serta zona berjarak $>500-1000 \mathrm{~m}$ (Gambar 2), sehingga dapat diketahui apa saja dampak yang ditimbulkan TPA Putri Cempo bagi permukiman di sekelilingnya serta seberapa jauh dampak tersebut terjadi.

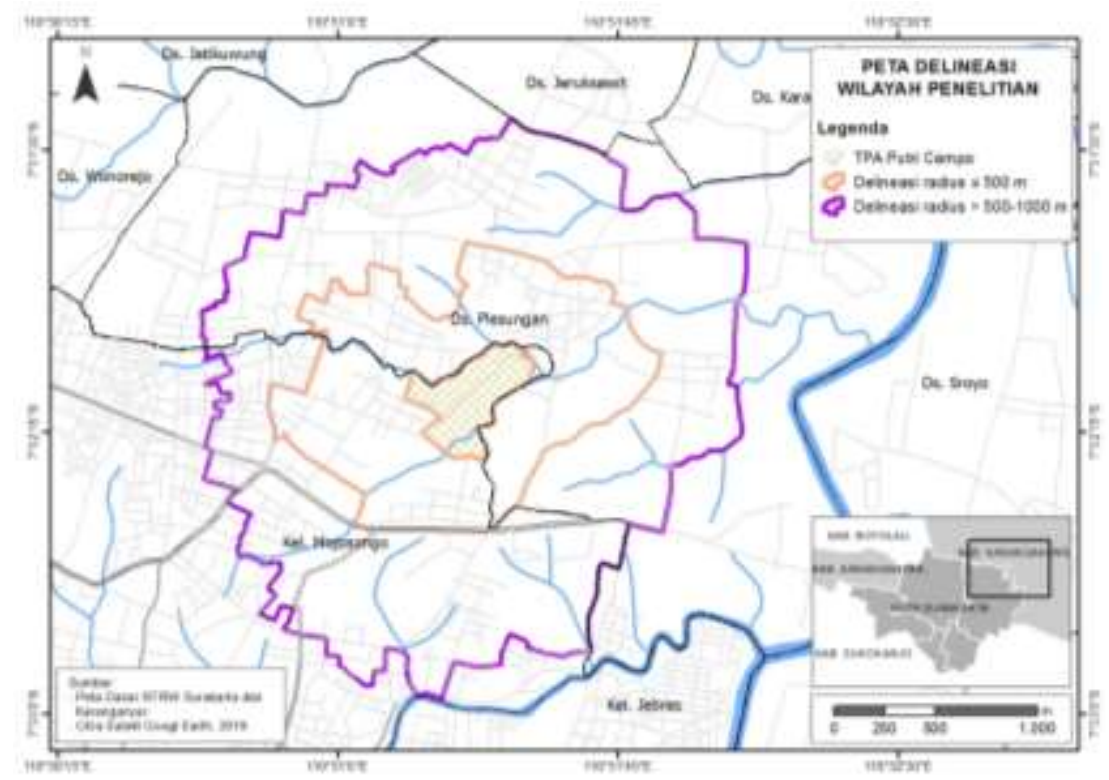

Gambar 2. Peta Ruang Lingkup Wilayah Penelitian 


\subsection{TEKNIK PENGUMPULAN DATA}

Pengumpulan data primer dilakukan dengan teknik observasi dan kuesioner. Observasi yang dilakukan adalah observasi terstruktur, yaitu observasi yang telah yang telah dirancang secara sistematis, tentang apa yang akan diamati, dan di mana tempatnya. Teknik observasi ini dilakukan untuk pengumpulan data kondisi fisik dan tata bangunan permukiman, persebaran usaha persampahan, timbunan sampah dan ceceran sampah, kondisi saluran drainase, persebaran dan kondisi RTH, serta kondisi jaringan jalan. Teknik kuesioner dilakukan untuk memperoleh informasi dan pendapat masyarakat tentang kualitas udara, kebisingan, jumlah kejadian kebakaran, gangguan kesehatan, serta kualitas air dangkal. Penentuan ukuran sampel untuk kuesioner dilakukan dengan rumus Slovin sebagai berikut.

$$
n=\frac{N}{1+\left(N \times e^{2}\right)}=\frac{8406 K K}{1+(8406 \times 0,01)} \approx 98 K K
$$

Dari jumlah sampel sebanyak $98 \mathrm{KK}$ tersebut, dibagi pada masing-masing zona wilayah penelitian, yaitu sebanyak $49 \mathrm{KK}$ pada masing-masing zona radius $\leq 500 \mathrm{~m}$ dan $>500$ - $1000 \mathrm{~m}$. Pemilihan sampel dilakukan secara insidental (sebarang orang yang ditemui peneliti) dengan ketentuan, yaitu setiap sampel rumah tangga diwakili oleh maksimal satu respon kuesioner dengan responden berusia produktif (15-64 tahun) yang dalam kesehariannya tinggal di wilayah penelitian.

Pengumpulan data sekunder dilakukan dengan mencari dan mengumpulkan data melalui instansi-instansi pemerintah maupun pengelola TPA Putri Cempo, serta lembaga swasta lain yang hasil publikasinya bersifat resmi. Data-data sekunder yang digunakan dalam penelitian ini antara lain data profil pengelolaan sampah Kota Surakarta dari Dinas Lingkungan Hidup Kota Surakarta, data aktivitas pengelolaan sampah di TPA Putri Cempo yang bersumber dari pengelola TPA Putri Cempo, data kejadian bencana kebakaran dari Dinas Pemadam Kebakaran Kota Surakarta dan Kabupaten Karanganyar, data kualitas udara dari Dinas Lingkungan Hidup Kota Surakarta dan Kabupaten Karanganyar, serta Peta Zona Nilai Tanah di wilayah penelitian dan sekitarnya dari Kantor Pertanahan Kota Surakarta dan Kabupaten Karanganyar.

\subsection{METODE ANALISIS}

Setelah data terkumpul, kemudian dilakukan analisis data dengan menggunakan teknik analisis deskriptif kuantitatif. Teknik analisis ini bermaksud untuk mendeskripsikan data yang telah diperoleh tanpa melakukan generalisasi. Analisis dampak aktivitas pengelolaan sampah TPA Putri Cempo terhadap kualitas permukiman sekitarnya dilakukan pada kedua zona wilayah penelitian, yaitu zona radius $\leq 500 \mathrm{~m}$ dan zona radius $>500-1000 \mathrm{~m}$. Penilaian terjadi atau tidaknya sub variabel dampak aktivitas pengelolaan sampah TPA Putri Cempo dilakukan dengan menggunakan indikator seperti pada Tabel 3. Hasil akhir analisis ini tidak bersifat secara keseluruhan, artinya bahwa identifikasi terjadinya dampak TPA Putri Cempo ini dilakukan per sub variabel.

Tabel 3. Indikator Variabel Dampak Aktivitas Pengelolaan Sampah TPA terhadap Kualitas Permukiman

\begin{tabular}{|c|c|c|c|c|}
\hline \multirow{2}{*}{ Variabel } & \multirow[b]{2}{*}{ Sub variabel } & \multirow[b]{2}{*}{ Parameter } & \multicolumn{2}{|c|}{ Indikator } \\
\hline & & & Terdampak & Tidak terdampak \\
\hline \multirow[t]{4}{*}{$\begin{array}{l}\text { Dampak } \\
\text { Pemilahan } \\
\text { sampah }\end{array}$} & $\begin{array}{l}\text { Adanya barak-barak } \\
\text { pemulung yang tidak } \\
\text { teratur }\end{array}$ & $\begin{array}{l}\text { Keberadaan barak-barak } \\
\text { pemulung (pemilah sampah) } \\
\text { yang tidak teratur }\end{array}$ & $\begin{array}{l}\text { Terdapat barak-barak yang } \\
\text { dihuni oleh pemulung, kondisi } \\
\text { bangunan tidak teratur }\end{array}$ & $\begin{array}{l}\text { Tidak terdapat barak-barak } \\
\text { pemulung }\end{array}$ \\
\hline & $\begin{array}{l}\text { Potensi ekonomi } \\
\text { penjualan hasil } \\
\text { pemilahan sampah }\end{array}$ & $\begin{array}{l}\text { Ada atau tidaknya penduduk } \\
\text { mendapatkan manfaat ekonomi } \\
\text { dari hasil pemilahan sampah }\end{array}$ & $\begin{array}{l}\text { Terdapat masyarakat yang } \\
\text { mendapat manfaat ekonomi } \\
\text { hasil pemilahan sampah }\end{array}$ & $\begin{array}{l}\text { Tidak terdapat usaha penjualan } \\
\text { hasil pemilahan sampah }\end{array}$ \\
\hline & $\begin{array}{l}\text { Pemanfaatan } \mathrm{RTH} \\
\text { sebagai tempat } \\
\text { penimbunan hasil } \\
\text { pemilahan sampah }\end{array}$ & $\begin{array}{l}\text { Ada atau tidaknya } \\
\text { penyalahgunaan fungsi RTH } \\
\text { sebagai tempat penimbunan } \\
\text { penimbunan hasil pemilahan } \\
\text { sampah }\end{array}$ & $\begin{array}{l}\text { RTH yang tersedia digunakan } \\
\text { sebagai tempat penimbunan } \\
\text { hasil pemilahan sampah }\end{array}$ & $\begin{array}{l}\text { RTH yang tersedia tidak } \\
\text { digunakan sebagai tempat } \\
\text { penimbunan hasil pemilahan } \\
\text { sampah }\end{array}$ \\
\hline & $\begin{array}{l}\text { Terganggunya arus lalu } \\
\text { lintas akibat } \\
\text { penyempitan jalan oleh } \\
\text { penimbunan hasil } \\
\text { pemilahan sampah }\end{array}$ & $\begin{array}{l}\text { kinerja jalan terhambat } \\
\text { dikarenakan penyempitan jalan } \\
\text { oleh penimbunan hasil } \\
\text { pemilahan sampah dan } \\
\text { aktivitas kendaraam } \\
\text { pengangkut }\end{array}$ & $\begin{array}{l}\text { Terjadi penyempitan jalan } \\
\text { akibat timbunan hasil } \\
\text { pemilahan sampah }\end{array}$ & $\begin{array}{l}\text { Tidak terjadi penyempitan jalan } \\
\text { akibat timbunan hasil pemilahan } \\
\text { sampah }\end{array}$ \\
\hline
\end{tabular}




\begin{tabular}{|c|c|c|c|c|}
\hline Variihal & & & & kator \\
\hline Variabel & Sub variabel & Parameter & Terdampak & Tidak terdampak \\
\hline $\begin{array}{l}\text { Dampak } \\
\text { Pengumpulan } \\
\text { dan }\end{array}$ & Tingginya kebisingan & $\begin{array}{l}\text { Nilai kebisingan di sekitar TPA } \\
\text { lebih tinggi dari baku tingkat } \\
\text { kebisingan }\end{array}$ & $\begin{array}{l}\text { Kebisingan }>55 \mathrm{~dB} \text { atau }>50 \% \\
\text { responden menyatakan } \\
\text { adanya kebisingan akibat TPA }\end{array}$ & $\begin{array}{l}\text { Kebisingan }<55 \mathrm{~dB} \text { atau } \leq 50 \% \\
\text { responden menyatakan adanya } \\
\text { kebisingan akibat TPA }\end{array}$ \\
\hline $\begin{array}{l}\text { Pengangkutan } \\
\text { sampah }\end{array}$ & $\begin{array}{l}\text { Timbulan ceceran } \\
\text { sampah }\end{array}$ & $\begin{array}{l}\text { Ada atau tidaknya timbulan } \\
\text { ceceran sampah dari } \\
\text { kendaraan pengangkut sampah }\end{array}$ & $\begin{array}{l}\text { Terdapat ceceran sampah } \\
\text { pada jalan yang dilalui truk } \\
\text { pengangkut sampah }\end{array}$ & $\begin{array}{l}\text { Tidak terdapat ceceran sampah } \\
\text { pada jalan yang dilalui truk } \\
\text { pengangkut sampah }\end{array}$ \\
\hline & Kerusakan jalan & $\begin{array}{l}\text { Perkerasan jalan yang rusak } \\
\text { akibat dilalui truk pengangkut } \\
\text { sampah }\end{array}$ & $\begin{array}{l}\text { Terdapat kerusakan pada jalan } \\
\text { seluas }>11 \% \text { dari luas } \\
\text { permukaan jalan }\end{array}$ & $\begin{array}{l}\text { Luas kerusakan jalan }<11 \% \text { luas } \\
\text { permukaan jalan }\end{array}$ \\
\hline Dampak Daur & Polusi udara akibat & Polusi udara yang ditimbulkan & $\mathrm{SO}_{2}>632 \mu \mathrm{g} / \mathrm{Nm}^{3}$ & $\mathrm{SO}_{2}<632 \mu \mathrm{g} / \mathrm{Nm}^{3}$ \\
\hline ulang sampah & proses daur ulang & industri daur ulang & $\mathrm{NO}_{2}>316 \mu \mathrm{g} / \mathrm{Nm}^{3}$ & $\mathrm{NO}_{2}<316 \mu \mathrm{g} / \mathrm{Nm}^{3}$ \\
\hline & & & $\begin{array}{l}\mathrm{O}_{3}>200 \mu \mathrm{g} / \mathrm{Nm}^{3} \\
\mathrm{CO}>15.000 \mu \mathrm{g} / \mathrm{Nm}^{3}\end{array}$ & $\begin{array}{l}\mathrm{O}_{3}<200 \mu \mathrm{g} / \mathrm{Nm}^{3} \\
\mathrm{CO}<15.000 \mu \mathrm{g} / \mathrm{Nm}^{3}\end{array}$ \\
\hline & Kerawanan kebakaran & Kerawanan kebakaran yang & Frekuensi kejadian kebakaran & Frekuensi kejadian kebakaran 0- \\
\hline & & $\begin{array}{l}\text { dilihat dari Frekuensi terjadinya } \\
\text { kebakaran di sekitar TPA }\end{array}$ & $\begin{array}{l}>5 \% \text { dari frekuensi kebakaran } \\
\text { dalam satu Kota }\end{array}$ & $\begin{array}{l}5 \% \text { dari frekuensi kebakaran } \\
\text { dalam satu Kota }\end{array}$ \\
\hline & $\begin{array}{l}\text { Potensi ekonomi usaha } \\
\text { dan industri daur ulang }\end{array}$ & $\begin{array}{l}\text { Ada atau tidaknya penduduk } \\
\text { yang mendapatkan manfaat } \\
\text { ekonomi dari usaha daur ulang }\end{array}$ & $\begin{array}{l}\text { Terdapat masyarakat yang } \\
\text { mendapat manfaat ekonomi } \\
\text { dari usaha daur ulang }\end{array}$ & $\begin{array}{l}\text { Tidak terdapat masyarakat yang } \\
\text { mendapat manfaat ekonomi dari } \\
\text { usaha daur ulang }\end{array}$ \\
\hline Dampak & Polusi udara dan & Apakah udara tercemar dan & Adanya kandungan gas $\mathrm{H}_{2} \mathrm{~S}$, & Tidak adanya kandungan gas \\
\hline $\begin{array}{l}\text { Penimbunan } \\
\text { akhir }\end{array}$ & timbulan debu & berdebu & $\begin{array}{l}\mathrm{NH}_{3} \text {, dan } \mathrm{CH}_{4} \text { ditandai dengan } \\
\text { bau busuk yang tajam dan } \\
\text { beraroma seperti telur busuk } \\
\mathrm{TSP}>230 \mu \mathrm{g} / \mathrm{Nm}^{3}\end{array}$ & $\begin{array}{l}\mathrm{H}_{2} \mathrm{~S}, \mathrm{NH}_{3} \text {,dan } \mathrm{CH}_{4} \text { (tidak ada) } \\
\text { bau busuk yang tajam dan } \\
\text { beraroma seperti telur busuk } \\
\mathrm{TSP}<230 \mu \mathrm{g} / \mathrm{Nm}^{3}\end{array}$ \\
\hline & $\begin{array}{l}\text { Penyumbatan saluran } \\
\text { drainase dan sungai }\end{array}$ & $\begin{array}{l}\text { Kualitas saluran drainase } \\
\text { (apakah tersumbat oleh }\end{array}$ & $\begin{array}{l}\text { Saluran drainase tersumbat } \\
\text { oleh ceceran/timbunan sampah }\end{array}$ & $\begin{array}{l}\text { Saluran drainase tidak tersumbat } \\
\text { ceceran/timbunan sampah }\end{array}$ \\
\hline
\end{tabular}

akibat kapasitas TPA timbunan/ceceran sampah atau yang telah overload tidak)

Rendahnya nilai tanah dan properti yang dibangun di sekitar lokasi TPA

Potensi peternakan sapi pemakan sampah organik Gangguan kesehatan pernafasan, pencernaan, dan iritasi
Nilai harga tanah dan unit hunian rata-rata di sekitar TPA Putri Cempo

Ada atau tidaknya usaha peternakan sapi pemakan sampah

Jumlah dan jenis keluhan kesehatan, terutama gangguan pernafasan dan pencernaan
Nilai tanah lebih rendah dari rata-rata nilai tanah di Surakarta

Terdapat masyarakat yang mendapat manfaat ekonomi dari usaha peternakan sapi $>50 \%$ responden kuesioner menyatakan masyarakat pernah mengalami gangguan kesehatan (pernafasan, pencernaan, iritasi) akibat TPA
Nilai tanah sama atau lebih dari rata-rata harga tanah di Surakarta

Tidak terdapat masyarakat mendapat manfaat ekonomi dari usaha peternakan sapi $\leq 50 \%$ responden kuesioner menyatakan masyarakat pernah mengalami gangguan kesehatan (pernafasan, pencernaan, iritasi) akibat TPA

\begin{tabular}{lll}
\hline $\begin{array}{l}\text { Dampak } \\
\text { Pengolahan } \\
\text { air lindi }\end{array}$ & Kualitas air bersih & $\begin{array}{l}\text { Kualitas air bersih yang } \\
\text { melayani kawasan sekitar TPA }\end{array}$ \\
kerusakan vegetasi & $\begin{array}{l}\text { Buruknya kondisi vegetasi } \\
\text { (layu, kering, mati) }\end{array}$ \\
& $\begin{array}{l}\text { Peluang ekonomi } \\
\text { melalui pemgolahan air } \\
\text { lindi sebagai pupuk cair }\end{array}$ & $\begin{array}{l}\text { Ada atau tidaknya penduduk } \\
\text { yang mendapatkan manfaat } \\
\text { ekoni dari usaha } \\
\text { pengolahan air lindi sebagai } \\
\text { pupuk cair }\end{array}$ \\
\hline
\end{tabular}

$\begin{array}{ll}>50 \% \text { masyarakat menyatakan } & 0-50 \% \text { masyarakat menyatakan } \\ \text { kualitas air buruk atau kadar } & \text { kualitas air buruk atau kadar } \\ \text { pencemar air dangkal melebihi } & \text { pencemar air dangkal belum } \\ \text { ambang batas menurut } & \text { melebihi ambang batas menurut } \\ \text { Permenkes No. 416 Th 1990 } & \text { Permenkes No. 416 Th 1990 } \\ \text { Vegetasi yang tumbuh di } & \text { Vegetasi yang tumbuh di } \\ \text { kawasan mengalami } & \text { kawasan hidup subur dan tidak } \\ \text { kekeringan atau mati } & \text { kering } \\ \text { Terdapat masyarakat yang } & \text { Tidak terdapat masyarakat yang } \\ \text { mendapat manfaat ekonomi } & \text { mendapat manfaat ekonomi dari } \\ \text { dari usaha pembuatan pupuk } & \text { usaha pembuatan pupuk cair }\end{array}$
pupuk cair

Setelah dilakukan analisis dampak dari aktivitas pengelolaan sampah TPA Putri Cempo pada dua zona kawasan yaitu radius $\leq 500 \mathrm{~m}$ dan radius $>500-1000 \mathrm{~m}$, akan diperoleh hasil mana saja sub variabel dampak yang terjadi pada sekitar TPA 
Putri Cempo dan janagkauan masing-masing dampak yang terjadi tersebut. Selanjutnya dapat diidentifikasi aspek kualitas permukiman apa saja yang memperoleh dampak dari masing-masing aktivitas pengelolaan sampah TPA Putri Cempo.

\section{HASIL DAN PEMBAHASAN}

Pada bagian ini akan membahas hasil kompilasi data-data yang diperoleh, baik data primer maupun sekunder, kemudian akan disertakan pembahasan mengenai kesesuaian antara temuan kondisi wilayah penelitian mengenai dampak aktivitas pengelolaan sampah pada TPA Putri Cempo dengan literatur yang telah disebutkan pada bagian sebelumnya. Berdasarkan data-data yang didapatkan, maka dapat dijelaskan hasil penelitian sebagai berikut:

\subsection{DAMPAK PEMILAHAN SAMPAH}

Dampak aktivitas pemilahan sampah yang pertama berkaitan dengan aspek kondisi fisik dan tata bangunan permukiman, yaitu terdapatnya permukiman kumuh berupa barak-barak pemulung dengan tata bangunan yang tidak teratur. Menurut fakta lapangan, aktivitas pemilahan sampah terjadi di dalam lokasi TPA Putri Cempo melibatkan sekitar 196 pemulung yang tinggal di sekitar TPA Putri Cempo dengan tempat tinggal yang cenderung mengelompok. Permukiman pemulung yang ditemukan pada wilayah penelitian memiliki luas sekitar 4,322 Ha yang tersebar di Dusun Jengglong, Dusun Sulurejo, Kampung Jatirejo, dan Kampung Randusari, seperti yang ditunjukkan dalam Gambar 3.

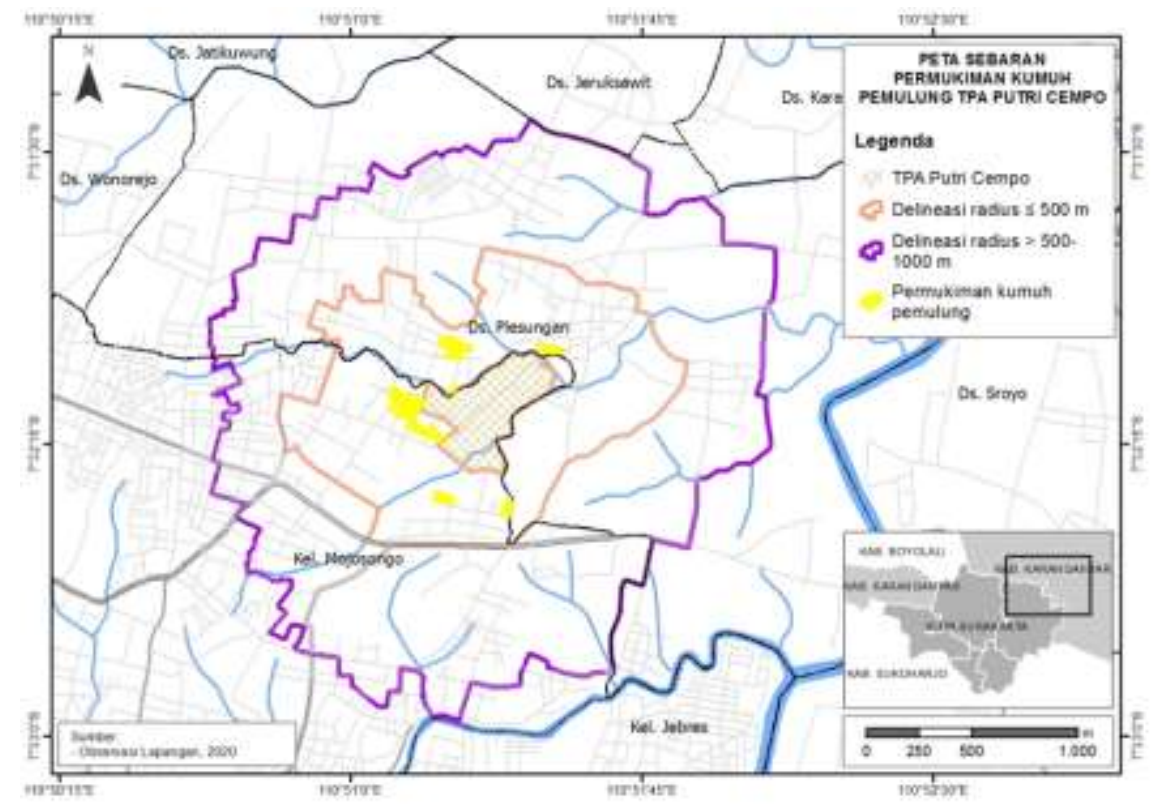

Gambar 3. Peta Sebaran Permukiman Kumuh Pemulung

Permukiman pemulung tersebut memiliki kondisi fisik bangunan yang kurang layak huni dengan tumpukan sampahsampah hasil kegiatan memulung di setiap muka rumah, seperti terlihat pada Gambar 4.
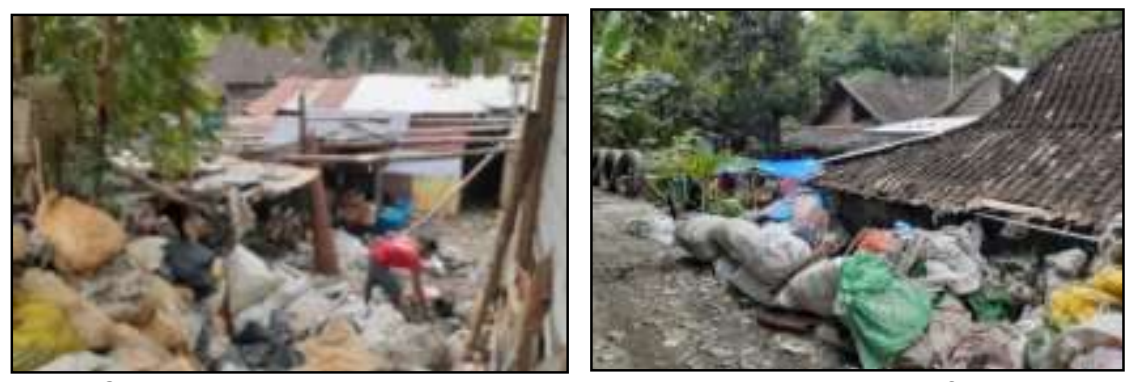

Gambar 4. Kondisi Permukiman Kvumuh Pemulung TPA Putri Cempo 
Dampak aktivitas pemilahan sampah yang kedua berhubungan dengan aspek perekonomian masyarakat, yaitu potensi sumber perekonomian masyarakat sekitarnya melalui usaha pemilahan sampah (Gambar 5). Berdasarkan hasil observasi lapangan, dan kuesioner yang dibagikan ke masyarakat, terutama pada zona radius $\leq 500 \mathrm{~m}$ memiliki mata pencaharian di sektor pemilahan sampah, baik pemulung maupun pemilah/pengepul sampah yang tersebar di Dusun Jengglong, Dusun Sulurejo, Kampung Jatirejo, dan Kampung Randusari.
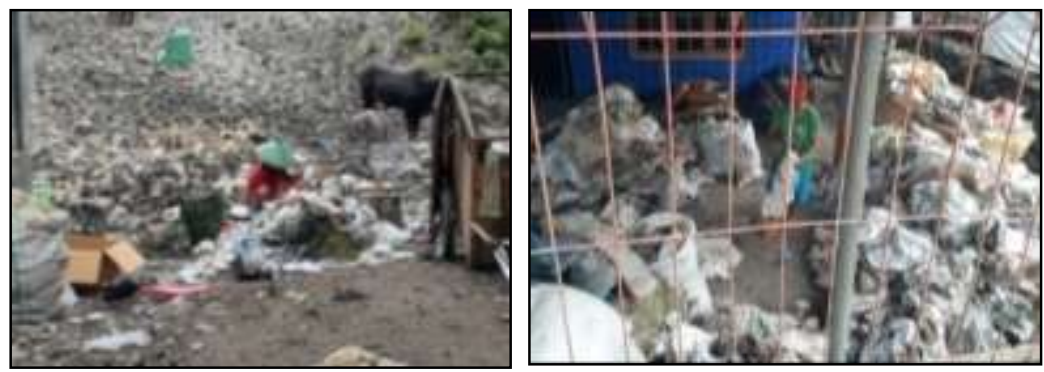

Gambar 5. Ilustrasi Usaha Pemilahan Sampah

Dampak aktivitas pemilahan sampah yang ketiga berkaitan dengan aspek kondisi sarana dan fasilitas umum, yaitu tempat penimbunan liar pada Ruang Terbuka Hijau (Gambar 7). Berdasarkan temuan observasi lapangan, ditemukan beberapa titik RTH yang dimanfaatkan untuk mengeringkan ataupun menimbun hasil pemilahan sampah sebelum disetorkan kepada industri daur ulang. Pemanfaatan RTH untuk penimbunan hasil pemilahan sampah ini terjadi pada 9 titik ruang terbuka di zona permukiman radius $\leq 500 \mathrm{~m}$ seperti yang ditampilkan pada Gambar 6 . Hasil pemilahan sampah yang ditimbun ataupun dijemur pada RTH dan badan jalan tersebut menyebabkan berkurangnya fungsi ekologis, estetika dan sosial RTH.

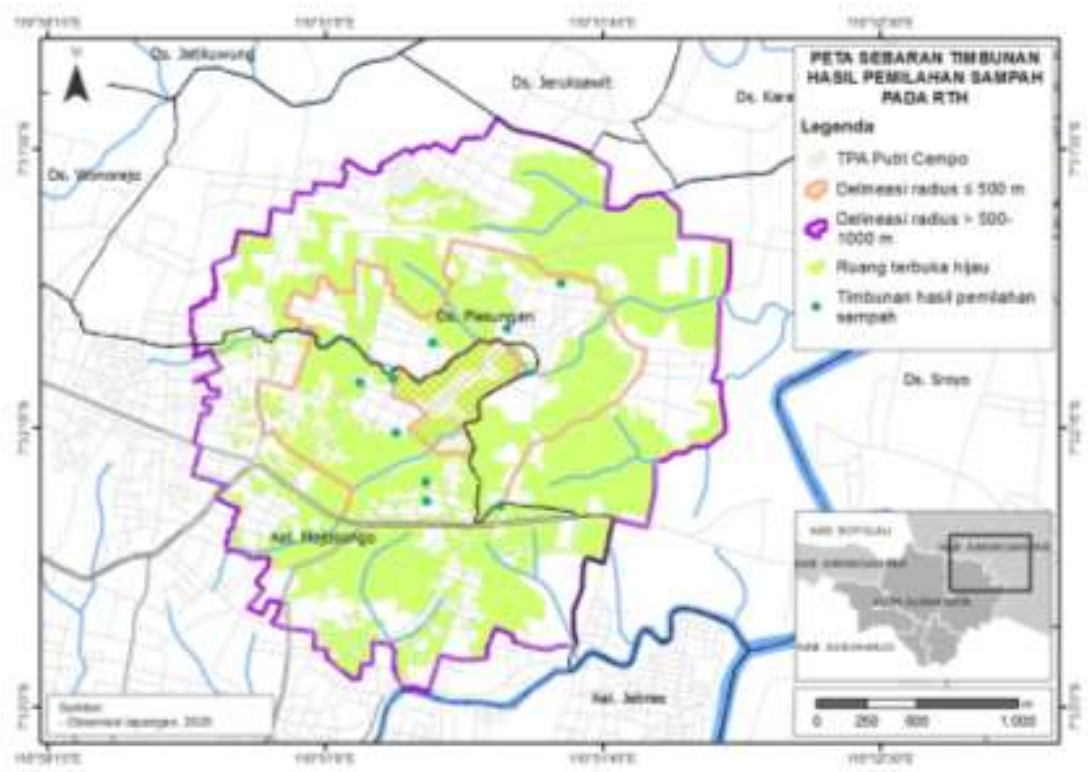

Gambar 6. Peta Sebaran Timbunan Sampah pada RTH
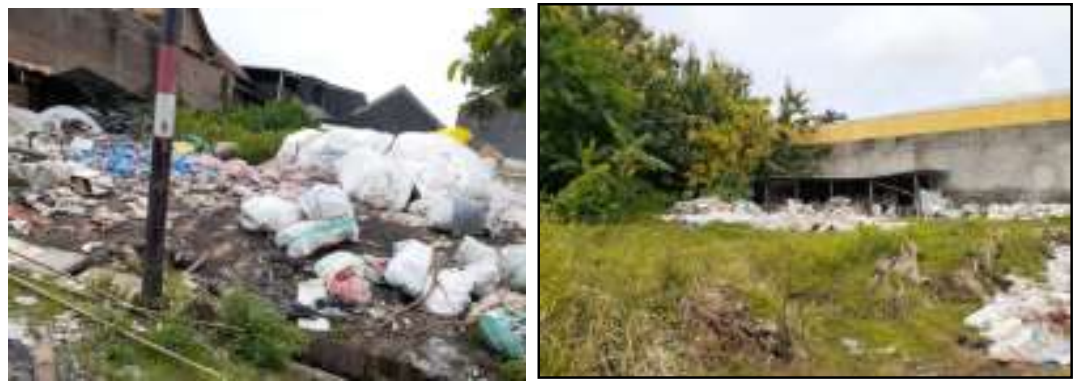

Gambar 7. Timbunan Hasil Pemilahan Sampah pada RTH 
Dampak aktivitas pemilahan sampah yang terakhir berhubungan dengan aspek aksesibilitas permukiman, yaitu timbunan hasil pemilahan sampah yang terjadi pada badan jalan. Berdasarkan hasil observasi lapangan, beberapa ruas jalan lingkungan, terutama pada zona permukiman radius $\leq 500 \mathrm{~m}$ dari TPA Putri Cempo juga digunakan untuk penimbunan/penjemuran sampah hasil pemilahan. Hasil pemilahan sampah yang ditimbun ataupun dijemur pada badan jalan tersebut berakibat pada sempitnya lebar permukaan jalan eksisting (Gambar 8), sehingga aksesibilitas permukiman menjadi berkurang.

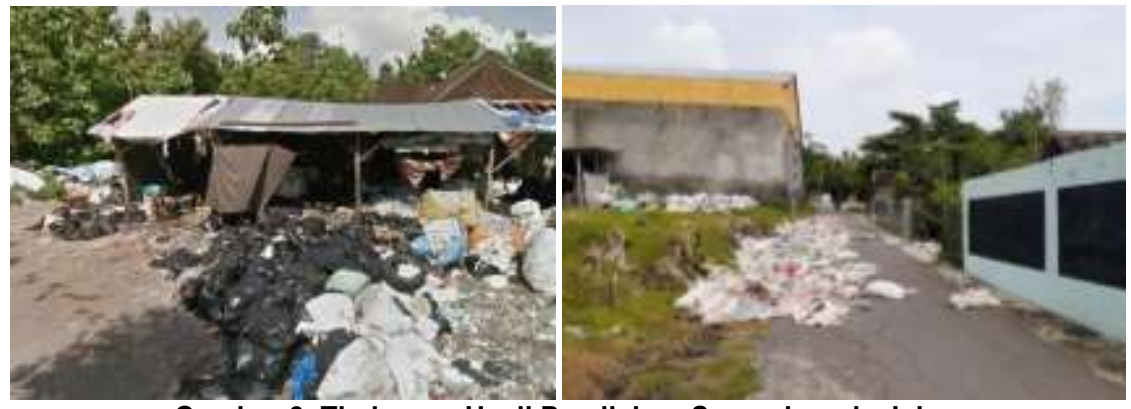

Gambar 8. Timbunan Hasil Pemilahan Sampah pada Jalan

Berdasarkan kompilasi data-data di atas yang kemudian dibandingkan dengan indikator dalam Tabel 3, maka dapat dianalisis dampak aktivitas pemilahan sampah yang terjadi pada kualitas permukiman radius $\leq 500 \mathrm{~m}$ dan radius $>500-1000$ m dari TPA Putri Cempo (Tabel 4).

Tabel 4. Identifikasi Dampak Aktivitas Pemilahan Sampah

\begin{tabular}{llcc}
\hline \multirow{2}{*}{ Variabel } & \multicolumn{1}{c}{ Sub Variabel } & \multicolumn{2}{c}{ Hasil } \\
\cline { 3 - 4 } $\begin{array}{llc}\text { Dampak } \\
\text { Pemilahan } \\
\text { sampah }\end{array}$ & $\begin{array}{l}\text { Adanya kawasan permukuman kumuh karena } \\
\text { keberadaan komunitas pemulung }\end{array}$ & Terdampak & Tidak Terdampak \\
& $\begin{array}{l}\text { Potensi ekonomi pemilahan sampah } \\
\text { Pemanfaatan RTH sebagai tempat penimbunan hasil } \\
\text { pemilahan sampah }\end{array}$ & Terdampak & Terdampak \\
& $\begin{array}{l}\text { Terganggunya arus lalu lintas akibat penyempitan jalan } \\
\text { oleh timbunan hasil pemilahan sampah }\end{array}$ & Terdampak \\
& Tidak Terdampak \\
\hline
\end{tabular}

\subsection{DAMPAK PENGUMPULAN DAN PENGANGKUTAN SAMPAH}

Dampak pengumpulan dan pengangkutan sampah yang pertama berkaitan dengan aspek keamanan dan kenyamanan lingkungan, yaitu timbulnya ceceran sampah yang merusak nilai visual kawasan akibat aktivitas pengangkutan sampah menuju TPA yang menggunakan kendaraan yang tidak memenuhi standar. Berdasarkan observasi lapangan dan wawancara dengan Dinas Lingkungan Hidup Kota Surakarta, sebagian kendaraan pengangkut sampah menuju TPA Putri Cempo tidak memiliki perlengkapan sesuai syarat kendaraan pengangkut sampah, yaitu penggunaan penutup sampah (minimal jaring) dan pengaman air sampah pada dasar kontainer, seperti terlihat dalam Gambar 9. Hal tersebut menyebabkan timbulnya ceceran sampah dan air sampah pada jalan yang dilalui pengangkut sampah, baik pada zona permukiman radius $\leq 500 \mathrm{~m}$ maupun $>$ 500-1000 m. Adanya ceceran sampah dan air sampah mengakibatkan timbulnya bau serta kesan kotor pada wilayah penelitian.

Dampak pengumpulan dan pengangkutan sampah yang kedua juga berkaitan dengan aspek kenyamanan lingkungan, yaitu tingginya kebisingan pada jalur yang dilalui kendaraan pengangkut sampah. Berdasarkan temuan lapangan, dampak berupa kebisingan tidak terjadi pada wilayah penelitian. Dari hasil kuesioner yang dibagikan ke masyarakat, 87,76\% pendapat masyarakat menyatakan tidak merasakan adanya kebisingan yang mengganggu akibat aktivitas pengangkutan sampah. Tidak terjadinya kebisingan pada wilayah penelitian disebabkan karena jalan lingkungan di kawasan permukiman hanya dilalui kendaraan seperti gerobak dan sepeda motor. Selain itu, keberadaan vegetasi/pepohonan yang rimbun juga mampu mengurangi kebisingan yang ditimbulkan kendaraan pengangkut sampah. 

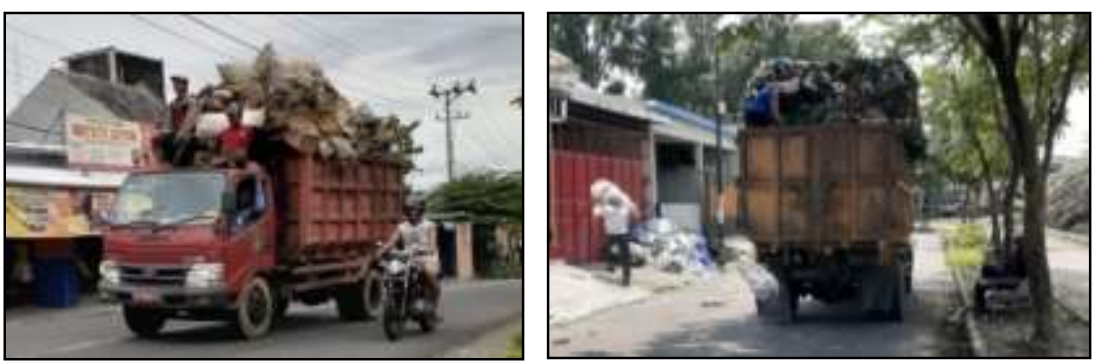

Gambar 9. Kondisi Kendaraan Pengumpul dan Pengangkut Sampah

Dampak aktivitas pengumpulan dan pengangkutan sampah yang terakhir berkaitan dengan aspek aksesibilitas permukiman, yaitu kerusakan jalan yang disebabkan kendaraan pengangkut sampah. Dari hasil observasi kondisi jalan, kerusakan jalan akibat aktivitas pengangkutan sampah yang ditemukan terjadi pada wilayah penelitian adalah sekitar 18,52\% dari total panjang jalan pada zona radius $\leq 500 \mathrm{~m}$ dan 4,89\% pada zona radius $>500-1000 \mathrm{~m}$ (Gambar 10 dan Tabel 5).

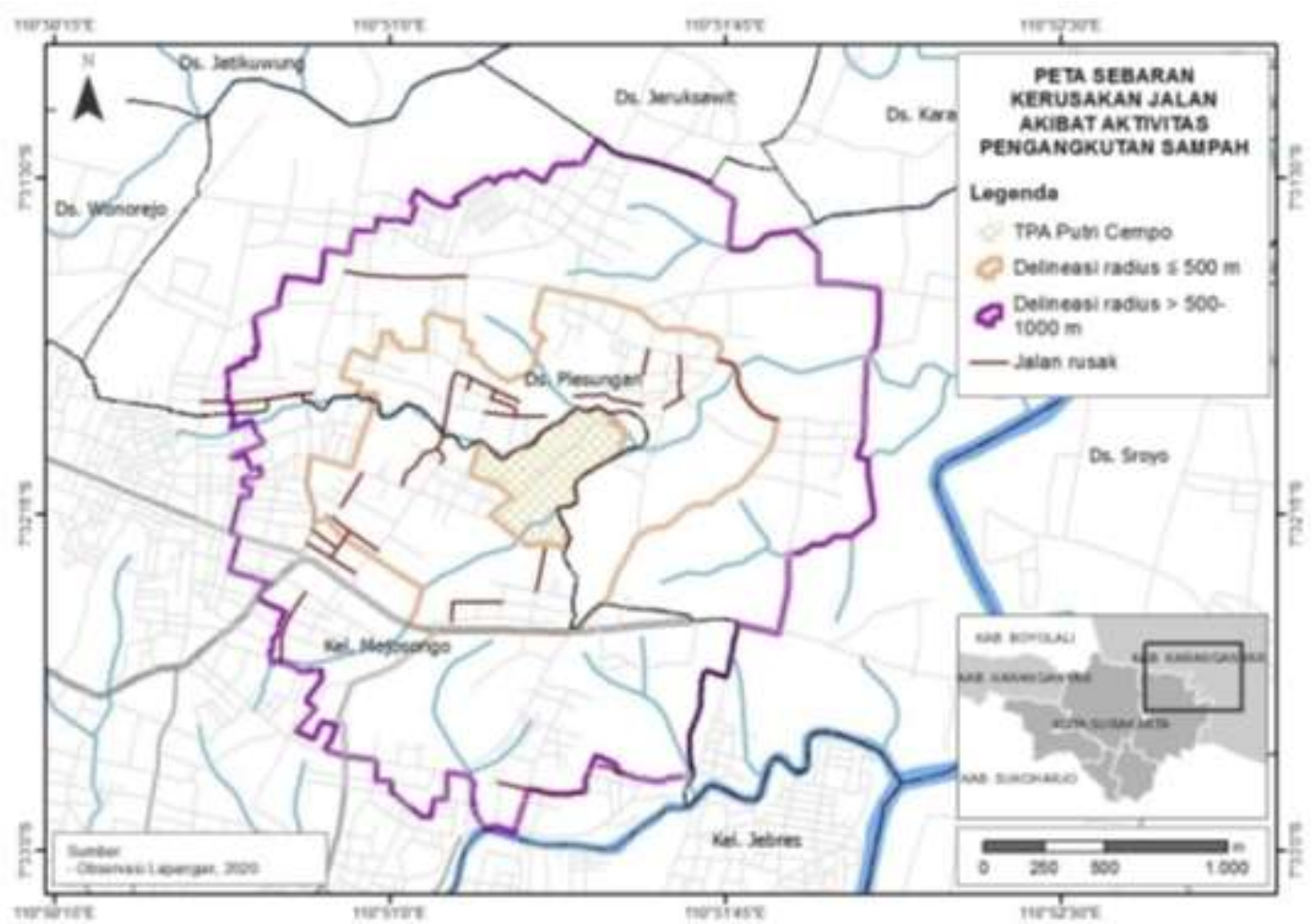

Gambar 10. Peta Sebaran Kerusakan Jalan Akibat Aktivitas Pengumpulan dan Pengangkutan Sampah

Tabel 5. Persentase Kerusakan Jalan

\begin{tabular}{ccc}
\hline No & Radius dari TPA Putri Cempo & Persentase panjang jalan rusak (\%) \\
\hline 1. & $\leq 500 \mathrm{~m}$ & $18,52 \%$ \\
& & (Klasifikasi : rusak berat) \\
2. & $>500-1000 \mathrm{~m}$ & $4,89 \%$ \\
& & (Klasifikasi : baik) \\
\hline
\end{tabular}

Berdasarkan kompilasi data-data di atas yang kemudian dibandingkan dengan indikator dalam Tabel 3, maka dapat diketahui dampak aktivitas pengumpulan dan pengangkutan sampah yang terjadi pada kualitas permukiman radius $\leq 500 \mathrm{~m}$ dan radius $>500 \mathrm{~m}$ dari TPA Putri Cempo (Tabel 6 ). 
Tabel 6. Identifikasi Dampak Aktivitas Pengumpulan dan Pengangkutan Sampah

\begin{tabular}{|c|c|c|c|}
\hline \multirow{2}{*}{ Variabel } & \multirow{2}{*}{ Sub Variabel } & \multicolumn{2}{|c|}{ Hasil } \\
\hline & & Radius $\leq 500 \mathrm{~m}$ & Radius $>500-1000 \mathrm{~m}$ \\
\hline \multirow{3}{*}{$\begin{array}{l}\text { Dampak } \\
\text { Pengumpulan dan } \\
\text { pengangkutan } \\
\text { sampah }\end{array}$} & Tingginya kebisingan & Tidak Terdampak & Tidak Terdampak \\
\hline & Timbulan ceceran sampah & Terdampak & Terdampak \\
\hline & Kerusakan jalan & Terdampak & Tidak Terdampak \\
\hline
\end{tabular}

Berdasarkan kompilasi dan analisis data di atas, beberapa permasalahan yang ditimbulkan oleh aktivitas pengumpulan dan pengangkutan sampah disebabkan karena standar kendaraan pengangkutan sampah yang digunakan belum memenuhi ketentuan yang berlaku. Optimalisasi aktivitas pengumpulan dan pengangkutan sampah dapat dilakukan dengan peningkatan kualitas kendaraan pengangkutan sampah dan perlengkapannya sehingga memenuhi standar yang berlaku dan mengurangi dampak yang ditimbulkan.

\subsection{DAMPAK DAUR ULANG SAMPAH}

Kegiatan daur ulang sampah adalah kegiatan pemrosesan sampah anorganik untuk dijadikan barang sekunder. Jenis sampah yang biasanya dapat didaur ulang adalah jenis sampah anorganik, seperti plastik, kertas, kaca, dan metal. Jika dilihat dari komposisi timbulan sampah TPA Putri Cempo, jenis-jenis sampah yang dapat didaur ulang memiliki persentase sebesar $29,19 \%$ dari seluruh timbulan sampah yang masuk ke TPA. Artinya, apabila berjalan optimal, sebenarnya aktivitas daur ulang sampah ini merupakan metode yang cukup potensial dalam mereduksi timbulan sampah TPA Putri Cempo.

Dampak daur ulang sampah yang pertama berhubungan dengan aspek kondisi lingkungan alami, yaitu terjadinya polusi udara. Berdasarkan hasil temuan penelitian, dampak polusi udara tidak terjadi pada wilayah penelitian karena ditemukan bahwa kandungan polutan udara $\left(\mathrm{NO}_{2}, \mathrm{O}_{3}\right.$, dan $\left.\mathrm{SO}_{2}\right)$ wilayah penelitian belum melewati ambang batas kadar polutan yang diizinkan (Tabel 7).

Tabel 7. Hasil Pemantauan Kualitas Udara di Sekitar TPA Putri Cempo

\begin{tabular}{|c|c|c|c|c|c|}
\hline \multirow{2}{*}{ No } & \multirow{2}{*}{ Lokasi Pemantauan } & \multicolumn{4}{|c|}{ Parameter } \\
\hline & & $\mathrm{NO}_{2}\left(\mu \mathrm{g} / \mathrm{Nm}^{3}\right)$ & $\mathrm{O}_{3}\left(\mu \mathrm{g} / \mathrm{Nm}^{3}\right)$ & $\mathrm{SO}_{2}\left(\mu \mathrm{g} / \mathrm{Nm}^{3}\right)$ & TSP/Debu $\left(\mu \mathrm{g} / \mathrm{Nm}^{3}\right)$ \\
\hline & BAKU MUTU & 316 & 200 & 632 & 230 \\
\hline \multicolumn{6}{|c|}{ Radius $\leq 500 \mathrm{~m}$} \\
\hline 1. & Lokasi TPA PC & 66,45 & 185,8 & $<47,9$ & 7,6 \\
\hline 2. & Jalan masuk TPA PC & 49,84 & 183,4 & $<47,9$ & 2,5 \\
\hline \multicolumn{6}{|c|}{ Radius $>500-1000 \mathrm{~m}$} \\
\hline 3. & Ring Road Mojosongo & 43,72 & 8,77 & 31,73 & 0,1 \\
\hline 4. & JL. Rinjani Selatan, Mojosongo & 8,28 & 4,32 & 10,86 & 0,07 \\
\hline
\end{tabular}

Sumber : DLH Kota Surakarta, 2015

Dampak daur ulang sampah yang kedua berkaitan dengan aspek keamanan dan kenyamanan lingkungan, yaitu meningkatnya kerawanan kebakaran akibat proses pembakaran dalam aktivitas daur ulang sampah. Berdasarkan temuan penelitian dari data jumlah kejadian kebakaran tahun 2019 menurut Dinas Pemadam Kebakaran Kota Surakarta, tingkat kerawanan kebakaran pada kedua zona permukiman tergolong sedang. Secara keseluruhan, terjadi sebanyak 12 kali kejadian kebakaran di wilayah penelitian. Dari 12 kejadian kebakaran yang terjadi, tidak ada satu pun yang terjadi pada unit usaha/industri daur ulang sampah, melainkan terjadi di area TPA Putri Cempo sebanyak 6 kali, dan 6 kejadian lainnya terjadi pada zona permukiman radius $>500-1000 \mathrm{~m}$. Dengan demikian, dapat disimpulkan bahwa aktivitas daur ulang sampah di TPA Putri Cempo tidak berdampak pada meningkatnya kerawanan kebakaran pada wilayah sekitarnnya.

Dampak daur ulang sampah yang terakhir berkaitan dengan aspek perekonomian masyarakat, yaitu memunculkan potensi perekonomian bagi masyarakat sekitar berupa usaha daur ulang sampah. Berdasarkan temuan penelitian, beberapa unit usaha daur ulang sampah ditemukan pada permukiman radius $\leq 500 \mathrm{~m}$ dan permukiman radius $>500-1000 \mathrm{~m}$ dari TPA. Dengan keberadaan perusahaan daur ulang tersebut, mampu membuka lapangan pekerjaan bagi masyarakat sebagai karyawan maupun sebagai pemulung atau pemilah sampah di dalam TPA Putri Cempo. 
Berdasarkan kompilasi data-data di atas yang kemudian dibandingkan dengan indikator dalam Tabel 3, maka dapat diketahui dampak aktivitas daur ulang sampah yang terjadi pada kualitas permukiman radius $\leq 500 \mathrm{~m}$ dan radius $>500 \mathrm{~m}$ dari TPA Putri Cempo (Tabel 8).

Tabel 8. Identifikasi Dampak Aktivitas Daur Ulang Sampah

\begin{tabular}{lllc}
\hline \multirow{2}{*}{ Variabel } & \multicolumn{1}{c}{ Sub Variabel } & Radius $\leq 500 \mathrm{~m}$ & Rasil \\
& \multicolumn{1}{c}{ Radius $>500-1000 \mathrm{~m}$} \\
\hline Dampak Daur & Polusi udara akibat proses daur ulang & Tidak Terdampak & Tidak Terdampak \\
Ulang Sampah & Kerawanan kebakaran & Tidak Terdampak & Tidak Terdampak \\
& Potensi ekonomi usaha dan industri daur ulang & Terdampak & Terdampak \\
\hline
\end{tabular}

Berdasarkan uraian di atas, metode daur ulang sampah merupakan metode pengolahan sampah merupakan cara yang cukup efektif dalam mengurangi timbunan sampah anorganik di TPA Putri Cempo. Aktivitas ini juga tidak banyak menimbulkan dampak negatif bagi permukiman sekitar. Dampak yang mungkin ditimbulkan antara lain polusi udara yang dihasilkan dari emisi pembakaran dalam rangkaian aktivitas daur ulang. Namun, hal tersebut dapat dihindari dengan minimalisasi emisi gas buang melalui penggunaan teknologi/mesin yang ramah lingkungan. Selain itu, aktivitas daur ulang juga memberikan manfaat ekonomi bagi pelakunya, mulai dari pemulung, pemilah sampah, hingga industri daur ulang sampah.

\subsection{DAMPAK PENIMBUNAN AKHIR SAMPAH}

Dampak penimbunan akhir sampah yang pertama berkaitan dengan aspek kondisi lingkungan alami, yaitu polusi udara berupa gas $\mathrm{CH}_{4}, \mathrm{H}_{2} \mathrm{~S}$, dan $\mathrm{NH}_{3}$ serta timbulan debu. Berdasarkan data pemantauan kualitas udara seperti pada Tabel 7 , diperoleh bahwa kandungan partikel-partikel debu pada udara di wilayah penelitian masih di bawah ambang batas yang diizinkan. Meskipun kandungan debu di bawah ambang batas, TPA Putri Cempo merupakan kontributor terbesar emisi metana $\left(\mathrm{CH}_{4}\right)$ di Kota Surakarta. Selain itu, berdasarkan kuesioner yang dibagikan ke masyarakat, 95,92\% pendapat masyarakat pada zona radius $\leq 500 \mathrm{~m}$ dan 46,94\% pendapat masyarakat pada zona radius $>500-1000 \mathrm{~m}$ merasakan bau yang tajam dari TPA Putri Cempo hampir setiap hari yang menandakan adanya kandungan gas-gas $\mathrm{CH}_{4}, \mathrm{H}_{2} \mathrm{~S}$, dan $\mathrm{NH}_{3}$ dalam udara (Gambar 11).

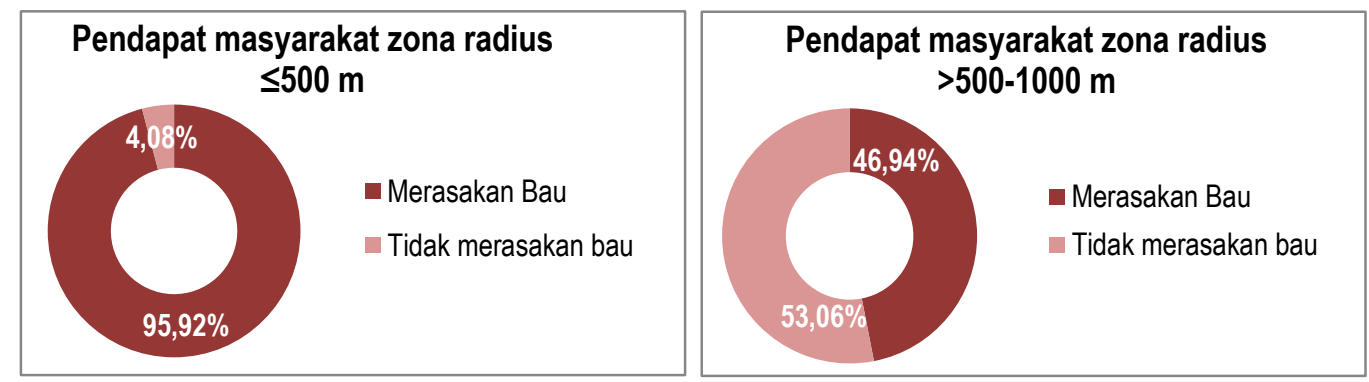

Gambar 11. Diagram Pendapat Masyarakat tentang Bau yang disebabkan TPA Putri Cempo

Dampak penimbunan akhir sampah yang berikutnya berkaitan dengan aspek kondisi prasarana dasar permukiman, yaitu tersumbatnya jaringan drainase yang dekat dengan TPA karena kapasitas TPA yang overload. Dari hasil observasi kondisi jaringan drainase yang ditunjukkan pada Gambar 12, diperoleh bahwa jaringan drainase di wilayah penelitian baik zona radius $\leq 500 \mathrm{~m}$ maupun radius $>500-1000 \mathrm{~m}$ tersumbat oleh sampah. Namun, hanya sungai yang melewati area TPA Putri Cempo dan saluran drainase di permukiman Randusari (di sebelah selatan TPA Putri Cempo) yang tersumbat sampah akibat luapan sampah TPA. Dengan demikian, dapat disimpulkan bahwa tersumbatnya drainase akibat aktivitas penimbunan sampah hanya terjadi pada zona permukiman radius $\leq 500 \mathrm{~m}$ dari TPA Putri Cempo. 

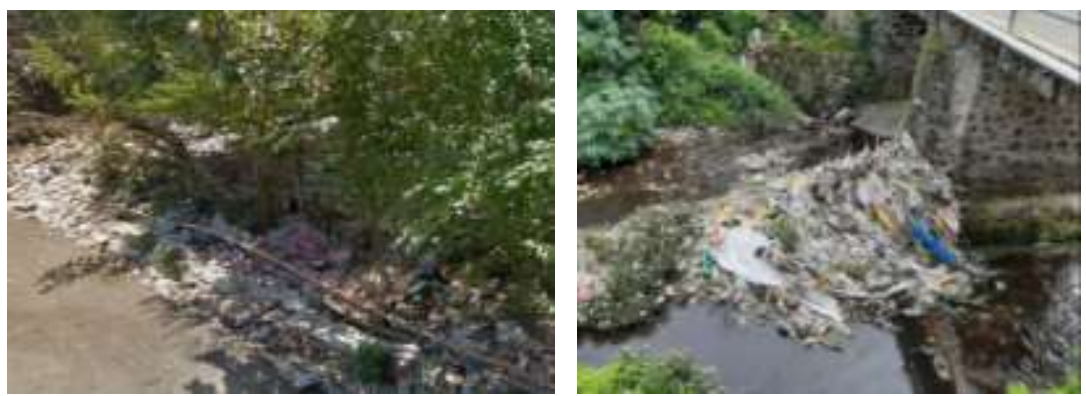

Gambar 12. Kondisi Saluran Drainase yang Tersumbat Sampah

Dampak penimbunan akhir sampah yang ketiga berkaitan dengan aspek keamanan dan kenyamanan lingkungan, yaitu berbagai munculnya gangguan kesehatan, terutama pernafasan, pencernaan, dan kulit. Berdasarkan 98 kuesioner yang dibagikan pada masyarakat, 55,01\% masyarakat pada zona radius $\leq 500 \mathrm{~m}$ pernah mengalami gangguan kesehatan seperti diare, pusing/mual, ISPA, dan gatal-gatal, sedangkan pada zona radius $>500-1000 \mathrm{~m}$, sekitar $6,12 \%$ pendapat masyarakat menyatakan pernah menderita gangguan kesehatan tersebut. Gangguan pusing, mual dan ISPA terjadi akibat adanya gas $\mathrm{CH}_{4}, \mathrm{H}_{2} \mathrm{~S}$, dan $\mathrm{NH}_{3}$ serta asap kebakaran TPA yang sering berhembus hingga permukiman. Keluhan diare terjadi karena lingkungan yang kurang bersih atau konsumsi air dan makanan yang terkontaminasi sampah ataupun hewan pembawa penyakit. Sedangkan keluhan gatal-gatal sering dialami oleh pemulung yang setiap harinya bersentuhan langsung dengan sampah-sampah di TPA Putri Cempo.

Dampak penimbunan akhir sampah yang keempat berkaitan dengan aspek lokasi dan aksesibilitas permukiman, yaitu rendahnya nilai tanah dan properti yang dibangun di sekitar lokasi TPA dikarenakan kondisi lingkungan yang kurang baik. Berdasarkan peta zona nilai tanah yang diakses melalui laman bhumi.atrbpn.go.id, wilayah penelitian baik zona radius $\leq 500$ $\mathrm{m}$ hingga radius $>500-1000 \mathrm{~m}$ memiliki nilai tanah antara $<\mathrm{Rp} 100.000$ hingga Rp 2.000.000/m2. Sedangkan wilayah sekitar, yaitu Kelurahan Mojosongo memiliki nilai tanah antara <Rp 100.000 hingga Rp 10.000.000/m2. Dengan demikian, dapat dikatakan bahwa nilai tanah wilayah penelitian lebih rendah dari nilai tanah di sekitarnya, seperti tampak pada Gambar 13.

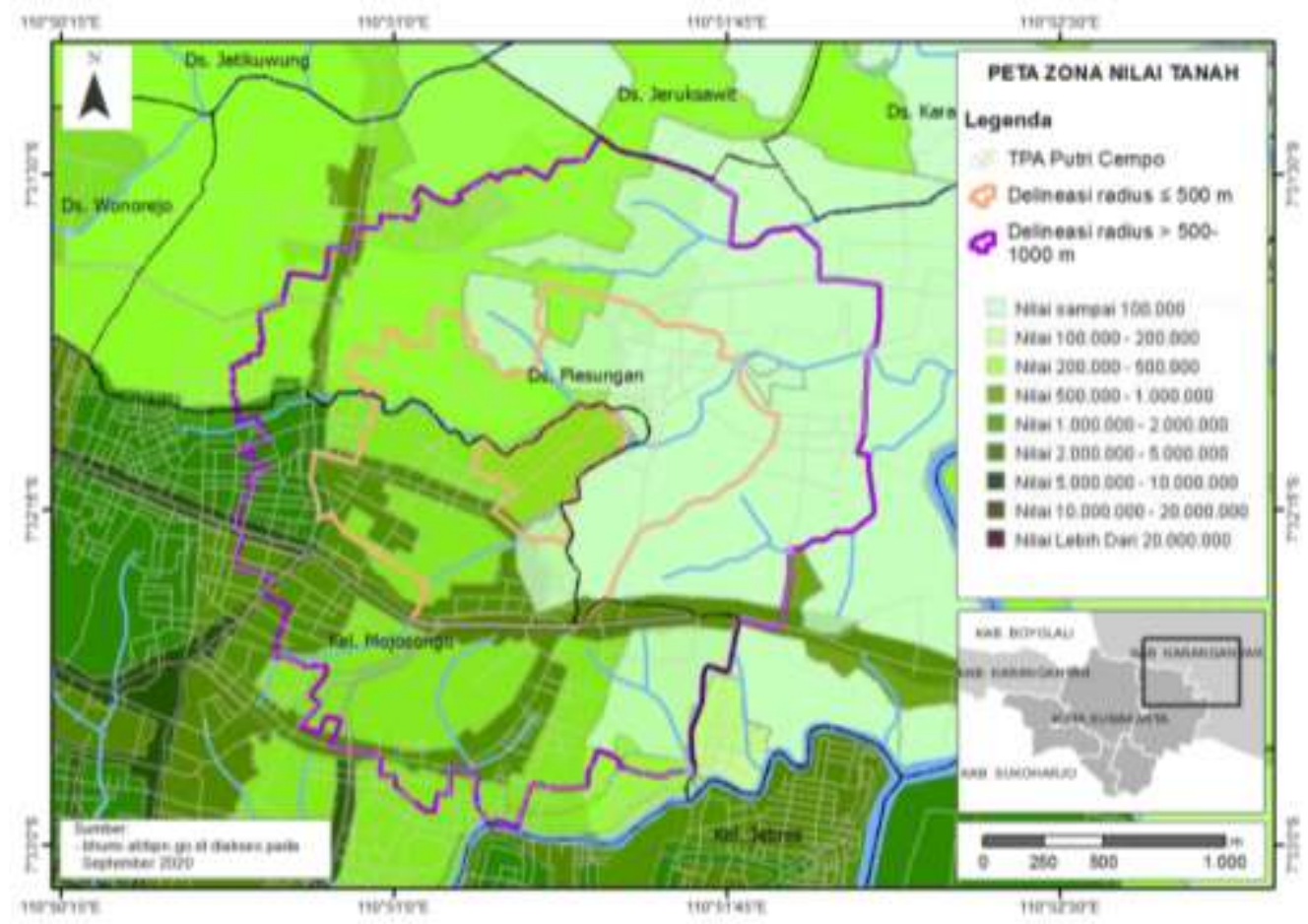

Sumber : Kementerian Agraria dan Tata Ruang, 2020

Gambar 13. Peta Zona Nilai Tanah 
Dampak penimbunan akhir sampah yang terakhir berkaitan dengan aspek perekonomian masyarakat, yaitu munculnya usaha peternakan sapi pemakan sampah di TPA. Berdasarkan temuan observasi lapangan, terdapat ribuan ekor sapi milik masyarakat pada zona radius $\leq 500 \mathrm{~m}$ yang sehari-hari dilepaskan pemiliknya untuk mencari makan di tumpukan sampah TPA Putri Cempo, seperti tampak pada Gambar 14. Meskipun kualitas daging sapi pemakan sampah masih menjadi perdebatan, namun sapi-sapi tersebut masih diperjualbelikan dan tetap diminati pembeli, terutama menjelang hari raya Idul Adha.

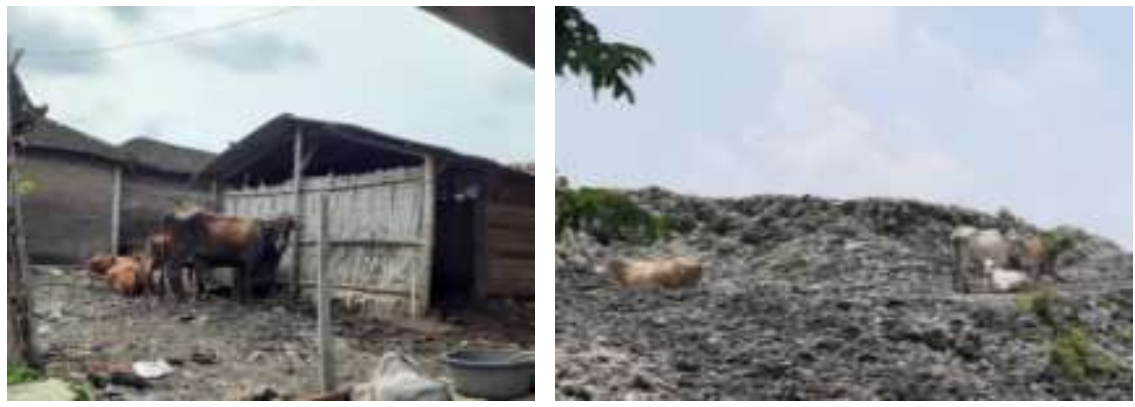

Gambar 14. Sapi Pemakan Sampah di TPA Putri Cempo

Berdasarkan kompilasi data-data di atas yang kemudian dibandingkan dengan indikator dalam Tabel 3, maka dapat diketahui dampak aktivitas penimbunan akhir sampah yang terjadi pada kualitas permukiman radius $\leq 500 \mathrm{~m}$ dan radius $>500$ m dari TPA Putri Cempo (Tabel 9).

Tabel 9. Identifikasi Dampak Aktivitas Penimbunan Akhir Sampah

\begin{tabular}{llcc}
\hline \multicolumn{1}{c}{ Variabel } & \multicolumn{1}{c}{ Sub Variabel } & Radius $\leq 500 \mathrm{~m}$ & $\begin{array}{c}\text { Hasil } \\
\text { Radius }>\mathbf{5 0 0 - 1 0 0 0 ~ m ~}\end{array}$ \\
\hline $\begin{array}{l}\text { Dampak } \\
\text { Penimbunan } \\
\text { akhir }\end{array}$ & $\begin{array}{l}\text { Polusi udara dan timbulan debu } \\
\text { Penyumbatan saluran drainase dan sungai akibat } \\
\text { kapasitas TPA yang telah overload } \\
\text { Rendahnya nilai tanah dan properti yang dibangun di } \\
\text { sekitar lokasi TPA }\end{array}$ & Terdampak & Tidak Terdampak \\
& $\begin{array}{l}\text { Potensi peternakan sapi pemakan sampah organik } \\
\text { Gangguan kesehatan pernafasan, pencernaan, dan } \\
\text { iritasi }\end{array}$ & Terdampak & Tidak Terdampak \\
& Terdampak & Terdampak \\
& Tidak Terdampak \\
& & Tidak Terdampak \\
\hline
\end{tabular}

\subsection{DAMPAK PENGOLAHAN AIR LINDI}

Dampak pengolahan air lindi yang pertama berkaitan dengan aspek kondisi lingkungan alami, yaitu perembesan air lindi ke dalam tanah yang dapat mencemari air tanah di bawahnya. Berdasarkan kondisi lapangan, pengolahan air lindi pada TPA Putri Cempo dilakukan dengan sistem kolam. Namun, keberadaan kolam ini tidak tersedia secara merata di seluruh zona timbunan sampah, sehingga beberapa zona penimbunan sampah tidak memiliki kolam pengolahan lindi dan mengalirkannya langsung ke lingkungan. Sedangkan pada zona yang memiliki kolam pengolahan lindi, kualitas instalasi yang dimiliki juga kurang baik. Pada musim hujan, kapasitas kolam lindi yang tersedia tidak mampu menampung air lindi dan air hujan sehingga meluber dan merembes ke permukaan tanah atau memasuki saluran drainase. Luberan air lindi yang masuk ke sungai menyebabkan pencemaran air sungai, sedangkan luberan yang merembes ke tanah dapat mencemari air yang berada di bawah lapisan tanah. Menurut hasil penelitian terdahulu mengenai kualitas air dangkal di sekitar TPA Putri Cempo, ditemukan bahwa terdapat beberapa indikator (kekeruhan, bau, rasa, $\mathrm{pH}$, kandungan nitrat dan bakteri coliform) pada sampel air tanah dangkal di Dusun Sulurejo, Kampung Jatirejo, dan Kampung Randusari (kawasan sebelah timur dan selatan TPA Putri Cempo) kurang sesuai dengan baku mutu air (Arifin, 2018; Masyifa, Hayati, \& Saputra, 2009; Yudhyarto, Utomo, \& Sulastoro, 2015).

Dampak pengolahan air lindi yang kedua juga berkaitan dengan aspek kondisi lingkungan alami, yaitu polusi tanah yang berakibat pada kerusakan vegetasi. Berdasarkan hasil observasi kondisi vegetasi di wilayah penelitian, tidak ditemukan adanya kerusakan vegetasi pada wilayah penelitian, baik pada zona radius $\leq 500 \mathrm{~m}$ maupun radius $>500-1000 \mathrm{~m}$. Kedua zona pada wilayah penelitian memiliki vegetasi dengan keadaan subur, rimbun, dan hijau seperti terlihat dalam Gambar 15. 


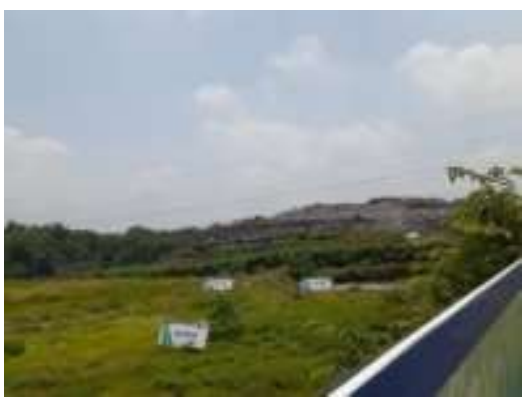

(a) Zona Radius $\leq 500 \mathrm{~m}$

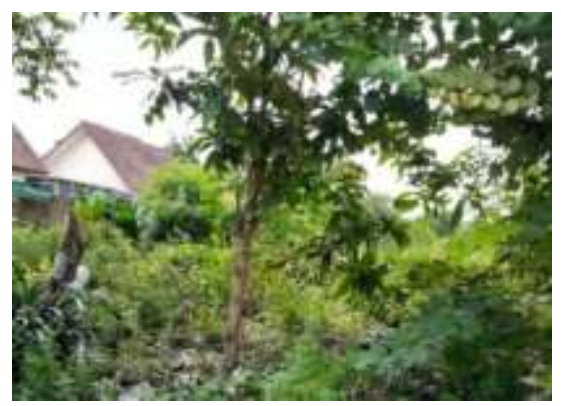

(b) Zona Radius >500-1000 m

Gambar 15. Kondisi Vegetasi Wilayah Penelitian

Dampak pengolahan air lindi yang terakhir berkaitan dengan aspek perekonomian masyarakat, yaitu munculnya usaha pengolah air lindi menjadi pupuk cair. Namun, pernyataan tersebut kurang sesuai karena berdasarkan fakta lapangan, kegiatan pengolahan air lindi dilakukan dengan metode kolam pengolahan oleh pengelola TPA dan tidak ditemukan usaha pengolahan air lindi menjadi pupuk cair pada permukiman di sekitar TPA Putri Cempo.

Berdasarkan kompilasi data-data di atas yang kemudian dibandingkan dengan indikator dalam Tabel 3 , maka dapat diketahui dampak aktivitas pengolahan air lindi yang terjadi pada kualitas permukiman radius $\leq 500 \mathrm{~m}$ dan radius $>500 \mathrm{~m}$ dari TPA Putri Cempo (Tabel 10).

Tabel 10. Identifikasi Dampak Aktivitas Pengolahan Air Lindi

\begin{tabular}{|c|c|c|c|}
\hline \multirow{2}{*}{ Variabel } & \multirow{2}{*}{ Sub Variabel } & \multicolumn{2}{|c|}{ Keterangan } \\
\hline & & Radius $\leq 500 \mathrm{~m}$ & Radius $>500-1000 \mathrm{~m}$ \\
\hline \multirow{3}{*}{$\begin{array}{l}\text { Dampak } \\
\text { Pengolahan air } \\
\text { lindi }\end{array}$} & Rendahnya kualitas air dangkal & Terdampak & Tidak Terdampak \\
\hline & Kerusakan vegetasi & Tidak Terdampak & Tidak Terdampak \\
\hline & $\begin{array}{l}\text { Peluang ekonomi melalui pengolahan air lindi } \\
\text { sebagai pupuk cair }\end{array}$ & Tidak Terdampak & Tidak Terdampak \\
\hline
\end{tabular}

Secara keseluruhan, dampak aktivitas pengelolaan sampah TPA Putri Cempo terhadap kualitas permukiman yang terjadi pada wilayah penelitian zona radius $\leq 500 \mathrm{~m}$ dan zona radius $>500-1000 \mathrm{~m}$ ditunjukkan dalam Tabel 11 .

Tabel 11. Hasil Identifikasi Dampak Aktivitas Pengelolaan Sampah TPA Putri Cempo terhadap Kualitas Permukiman

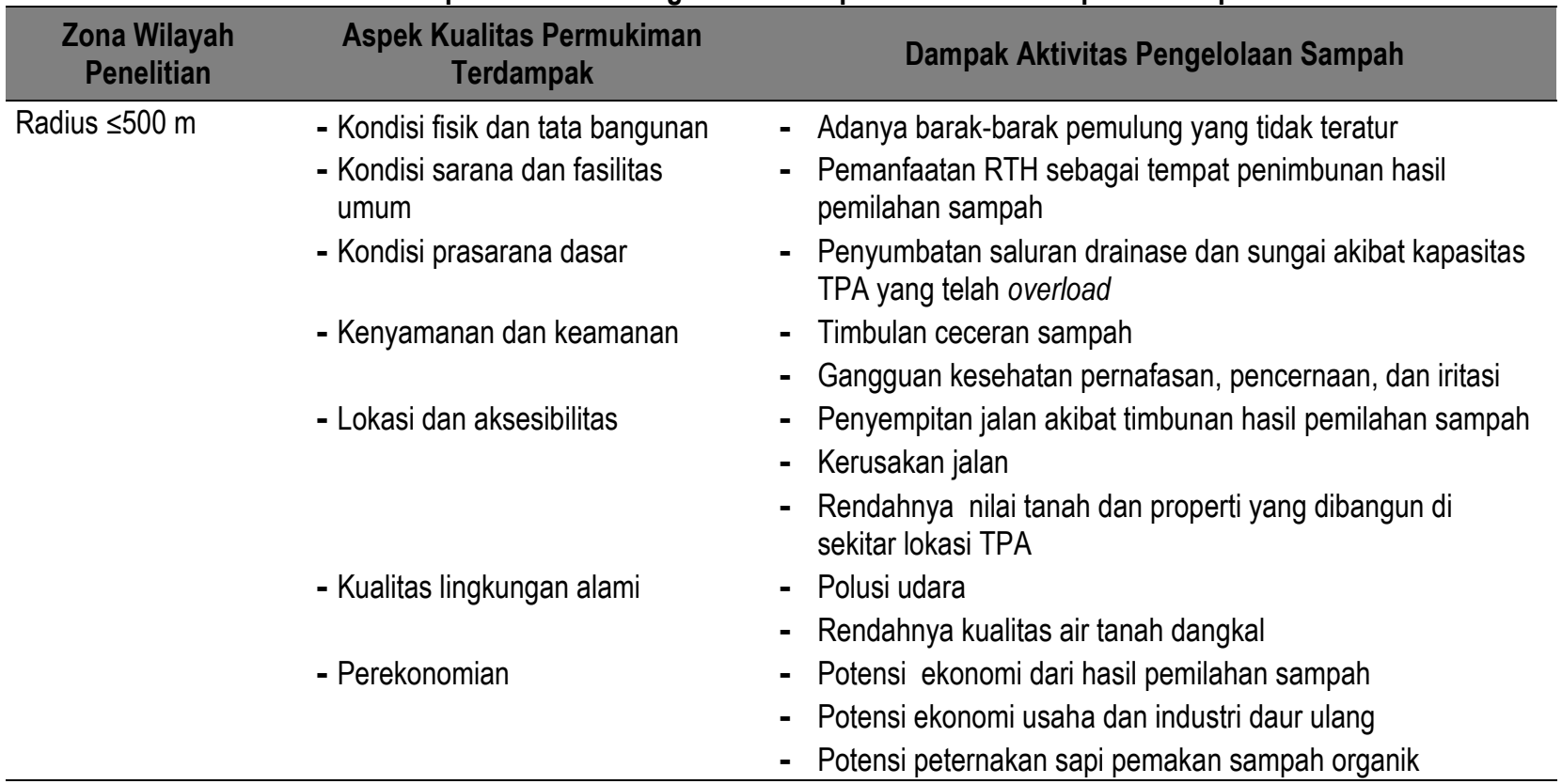




\begin{tabular}{cll}
$\begin{array}{c}\text { Zona Wilayah } \\
\text { Penelitian }\end{array}$ & \multicolumn{1}{c}{$\begin{array}{c}\text { Aspek Kualitas Permukiman } \\
\text { Terdampak }\end{array}$} & \multicolumn{1}{c}{ Dampak Aktivitas Pengelolaan Sampah } \\
\hline Radius $>500-1000 \mathrm{~m}$ & - Kenyamanan dan keamanan & - Timbulan ceceran sampah \\
& - Lokasi dan aksesibilitas & - Rendahnya nilai tanah dan properti yang dibangun di \\
& - Perekonomian & - Potensi ekonomi usaha dan industri daur ulang \\
\hline
\end{tabular}

\section{KESIMPULAN}

Aktivitas pengelolaan sampah TPA Putri Cempo terdiri dari lima aktivitas, yaitu pemilahan sampah, pengumpulan dan pengangkutan sampah, daur ulang sampah, penimbunan akhir, dan pengolahan air lindi. Kelima aktivitas tersebut berdampak terhadap kualitas permukiman di sekitarnya. Dilihat dari aspek kualitas permukiman yang terdampak oleh aktivitas pengelolaan sampah TPA Putri Cempo, permukiman beradius $\leq 500 \mathrm{~m}$ dari TPA Putri Cempo memperoleh dampak yang lebih besar dibandingkan dampak pada permukiman beradius $>500-1000 \mathrm{~m}$.

Pada zona radius $\leq 500 \mathrm{~m}$, aktivitas pengelolaan sampah TPA Putri Cempo berdampak negatif pada kualitas permukiman dari aspek kondisi fisik dan tata bangunan, kondisi sarana dan fasilitas umum, kondisi prasarana, keamanan dan kenyamanan lingkungan, lokasi dan aksesibilitas, dan kondisi lingkungan alami. Di sisi lain, aktivitas TPA Putri Cempo juga memberikan kesempatan bagi berkembangnya aspek perekonomian di zona ini dengan peluang-peluang usaha persampahan yang tercipta. Sedangkan pada zona radius $>500-1000 \mathrm{~m}$, aktivitas pengelolaan sampah TPA Putri Cempo berdampak negatif pada aspek keamanan dan kenyamanan lingkungan serta lokasi dan aksesibilitas, namun juga menjadi peluang pada aspek perekonomian.

Karena berbagai dampak yang ditimbulkan oleh aktivitas TPA Putri Cempo, beberapa upaya peningkatan kualitas permukiman di sekitar TPA Putri Cempo perlu dilakukan, seperti perbaikan rumah tidak layak huni, perbaikan jaringan jalan lingkungan, optimalisasi jaringan drainase dan air bersih, optimalisasi pemanfaatan RTH, serta pemantauan kualitas lingkungan secara berkala. Selain itu, sistem pengelolaan sampah yang lebih ramah lingkungan dan berkelanjutan juga perlu dioptimalkan dengan mengutamakan pada reduksi timbulan sampah melalui konsep 3R sehingga mampu mengurangi produksi sampah yang akan ditimbun di TPA Putri Cempo.

\section{DAFTAR PUSTAKA}

Adi, K., Wesnawa, I. G. A., \& Astawa, I. B. M. (2013). Kajian Kualitas Lingkungan Permukiman Skala Mikro di Desa Penyabangan Kecamatan Gerokgak. Jurnal Kesehatan Lingkungan, 4(1), 1-5. https://doi.org/10.23887/jpg.v4i1.20538

Alam, P., \& Ahmade, K. (2013). Impact of Solid Waste on Health and the Environment. International Journal of Sustainable Development and ..., 2(1), 165-168. Diakses dari https://www.researchgate.net/publication/306150450_Impact_of_Solid_Waste_on_Health_and_The_Environment

Arifin, H. A. (2018). Pengaruh Jarak Sumur dari Tempat Pembuangan Akhir Sampah Putri Cempo Terhadap Kualitas Air Sumur Warga Sulurejo. Universitas Muhammadiyah Surakarta.

Bandara, N., \& Hettiaratchi, J. P. A. (2010). Environmental Impacts with Waste Disposal Practices in a Suburban Municipality in Sri Lanka. International Journal of Environment and Waste Management, 6(1/2), 107-116. https://doi.org/10.1504/IJEWM.2010.033987

Barzehkar, M., Dinan, N. M., Mazaheri, S., Tayebi, R. M., \& Brodie, G. I. (2019). Landfill Site Selection Using GIS-Based Multi-Criteria Evaluation (Case Study: SaharKhiz Region Located in Gilan Province in Iran). SN Applied Sciences, 1(1082), 1-11. https://doi.org/10.1007/s42452-019-1109-9

Damanhuri, E., \& Padmi, T. (2010). Diktat Pengelolaan Sampah. Bandung: Fakultas Teknik Sipil dan Lingkungan Institut Teknologi Bandung.

Dinas Lingkungan Hidup Kota Surakarta. (2015). Rekapitulasi Hasil Pemantauan Kualitas Udara Ambien Kota Surakarta Tahun 2015. Diakses dari https://dlh.surakarta.go.id/new/?p=ss\&id=238

Doxiadis, C. A. (1970). Ekistics, the Science of Human Settlements. Science, 170(3956), 393-404. https://doi.org/10.1126/science.170.3956.393 
Dursun, P., \& Saglamer, G. (2009). Analysing Housing Quality: Belerko Housing Settlement, Trabzon, Turkey. Open House International, 34(4), 46-56. https://doi.org/10.1108/OHI-04-2009-B0006

Environment Agency UK. (2001). Scoping The Environmental Impacts of Demolition and Decommissioning Works. In Scoping Guidance on the Environmental Impact Assessment of Projects. Diakses dari https://assets.publishing.service.gov.uk/government/uploads/system/uploads/attachment_data/file/297126/geho0411btrh-e-e.pdf

Giusti, L. (2009). A Review of Waste Management Practices and Their Impact on Human Health. Waste Management, 29(8), 2227-2239. https://doi.org/10.1016/j.wasman.2009.03.028

Karina, S. N., Utomo, D. H., \& Budijanto. (2013). Analisis Karakteristik Dan Prakiraan Volume Sampah Tahun 2013-2020 Di Tempat Pembuangan Akhir (Tpa) Gedangkeret Kabupaten Jombang (Universitas Negeri Malang). Universitas Negeri Malang. Diakses dari http://repository.um.ac.id/id/eprint/53149

Kementerian Agraria dan Tata Ruang. (2020). Bhumi ATR/BPN. Diakses dari https://bhumi.atrbpn.go.id/

Lesmana, R. Y. (2016). Layanan Persampahan di Kota Surakarta dengan Pemetaan Barbasis Sistem Informasi Geografis. Media IImiah Teknik Lingkungan, 1(1), 11-21. https://doi.org/10.33084/mitl.v1i1.135

Luong, N. D., Giang, H. M., Thanh, B. X., \& Hung, N. T. (2013). Challenges for Municipal Solid Waste Management Practices in Vietnam. Waste Tech, 1(1), 17-21. https://doi.org/10.12777/wastech.1.1.17-21

Masyifa, Y., Hayati, N. A., \& Saputra, M. R. (2009). Pencemaran Air Tanah Di Sekitar TPA Putri Cempo, Kelurahan Mojosongo (p. 29). p. 29. Banjarmasin: Fakultas Teknik Universitas Lambung Mangkurat. Diakses dari https://id.scribd.com/doc/102661104/Pencemaran-Air-Tanah-Di-Sekitar-TPA-Putri-Cempo-Kelurahan-Mojosongo-Kota-SurakartaPropinsi-Jawa-Tengah

Mornya, A. A., Yola, L., \& Rafee, M. (2010). Identification of Landfill Sites by Using GIS and Multi-Criteria Method in Batam , Indonesia. International Graduate Conference on Engineering Siences and Humanities 2010. Johor. Diakses dari https://www.academia.edu/545126

Nugroho, R. A. (2017). Konsep Manajemen Batik Solo Trans Sebagai Pendukung Sektor Pariwisata di Kota Surakarta. Institut Teknologi Sepuluh Nopember.

Omran, A., \& Gavrilescu, M. (2008). Municipal Solid Waste Management in Developing Countries: A Perspective on Vietnam. Environmental Engineering and Management Journal, 7(4), 469-478. https://doi.org/10.30638/eemj.2008.070

Peraturan Menteri PUPR No. 19 Tahun 2012 tentang Pedoman Penataan Ruang Kawasan Sekitar Tempat Pemrosesan Akhir Sampah.

Peraturan Menteri PUPR No. 3 Tahun 2013 tentang Penyelenggaraan Prasarana dan Sarana Persampahan dalam Penanganan Sampah Rumah Tangga dan Sampah Sejenis Sampah Rumah Tangga.

Pratama, A. N. (2016). Pengolahan Sampah di TPA Putri Cempo Mojosongo Surakarta. Universitas Sebelas Maret.

Sugiyono. (2014). Metode Penelitian Pendidikan Pendekatan Kuantitatif, Kualitatif, dan R\&D. Bandung: Alfabeta.

Sunarhadi, M. A., Dahroni, D., \& Priyono, P. (2005). Identification of Settlements Quality in Pekanbaru Slums. Forum Geografi, 19(1), 5565. https://doi.org/10.23917/forgeo.v19i1.4570

Umutesi, O. (2018). Collection and Technology of Solid Waste in Mojosongo Landfill, TPA Putri Cempo and Their Relation to The Quality of Groundwater. Universitas Sebelas Maret.

Undang-Undang Republik Indonesia No.18 Tahun 2008 tentang Pengelolaan Sampah.

Wang, G., Qin, L., Li, G., \& Chen, L. (2009). Landfill Site Selection Using Spatial Information Technologies and AHP: A Case Study in Beijing, China. Journal of Environmental Management. Journal of Environmental Management, 90(8), 2414-2421. https://doi.org/10.1016/j.jenvman.2008.12.008

Yudhyarto, B., Utomo, B., \& Sulastoro. (2015). Pengaruh Tempat Pembuangan Akhir Sampah Putri Cempo Surakarta Terhadap Kualitas Air Tanah Dangkal Penduduk Sekitar. Jurnal MATRIKS TEKNIK SIPIL, 3(2), 564-569. https://doi.org/10.20961/mateksi.v3i2.37214 